\title{
Proteomic responses of oceanic Synechococcus WH8102 to phosphate and zinc scarcity and cadmium additions
}

\author{
Alysia D. Cox ${ }^{1,2+}$ and Mak A. Saito ${ }^{2 *}$ \\ ${ }^{\prime}$ MITMHOI Joint Program in Chemical Oceanography, Massachusetts Institute of Technology and Woods Hole Oceanographic Institution, Woods Hole and \\ Cambridge, MA, USA \\ ${ }^{2}$ Marine Chemistry and Geochemistry Department, Woods Hole Oceanographic Institution, Woods Hole, MA, USA
}

\section{Edited by:}

Partha Basu, Duquesne University, USA

\section{Reviewed by:}

Eric Boyd, Montana State University, USA

Luis G. C. Pacheco, Federal

University of Bahia, Brazil

\section{*Correspondence:}

Mak A. Saito, Marine Chemistry and Geochemistry Department, Woods Hole Oceanographic Institution, 360 Woods Hole Road, Woods Hole, MA 02543, USA

e-mail:msaito@whoi.edu

${ }^{\dagger}$ Present address:

Alysia D. Cox, School of Earth and Space Exploration, Arizona State

University, Tempe, AZ, USA
Synechococcus sp. WH 8102 is a motile marine cyanobacterium isolated originally from the Sargasso Sea. To test the response of this organism to cadmium $(\mathrm{Cd})$, generally considered a toxin, cultures were grown in a matrix of high and low zinc $(\mathrm{Zn})$ and phosphate $\left(\mathrm{PO}_{4}{ }^{3-}\right)$ and were then exposed to an addition of $4.4 \mathrm{pM}$ free $\mathrm{Cd}^{2+}$ at mid-log phase and harvested after $24 \mathrm{~h}$. Whereas $\mathrm{Zn}$ and $\mathrm{PO}_{4}{ }^{3-}$ had little effect on overall growth rates, in the final $24 \mathrm{~h}$ of the experiment three growth effects were noticed: (i) low $\mathrm{PO}_{4}{ }^{3-}$ treatments showed increased growth rates relative to high $\mathrm{PO}_{4}{ }^{3-}$ treatments, (ii) the $\mathrm{Zn} /$ high $\mathrm{PO}_{4}{ }^{3-}$ treatment appeared to enter stationary phase, and (iii) $\mathrm{Cd}$ increased growth rates further in both the low $\mathrm{PO}_{4}{ }^{3-}$ and $\mathrm{Zn}$ treatments. Global proteomic analysis revealed that: (i) $\mathrm{Zn}$ appeared to be critical to the $\mathrm{PO}_{4}{ }^{3-}$ response in this organism, (ii) bacterial metallothionein (SmtA) appears correlated with $\mathrm{PO}_{4}{ }^{3-}$ stress-associated proteins, (iii) $\mathrm{Cd}$ has the greatest influence on the proteome at low $\mathrm{PO}_{4}{ }^{3-}$ and $\mathrm{Zn}$, (iv) $\mathrm{Zn}$ buffered the effects of $\mathrm{Cd}$, and (v) in the presence of both replete $\mathrm{PO}_{4}{ }^{3-}$ and added $\mathrm{Cd}$ the proteome showed little response to the presence of $\mathrm{Zn}$. Similar trends in alkaline phosphate (ALP) and SmtA suggest the possibility of a $\mathrm{Zn}$ supply system to provide $\mathrm{Zn}$ to ALP that involves SmtA. In addition, proteome results were consistent with a previous transcriptome study of $\mathrm{PO}_{4}{ }^{3-}$ stress (with replete $\mathrm{Zn}$ ) in this organism, including the greater relative abundance of ALP (PhoA), ABC phosphate binding protein (PstS) and other proteins. Yet with no $\mathrm{Zn}$ in this proteome experiment the $\mathrm{PO}_{4}{ }^{3-}$ response was quite different including the greater relative abundance of five hypothetical proteins with no increase in PhoA or PstS, suggesting that $\mathrm{Zn}$ nutritional levels are connected to the $\mathrm{PO}_{4}{ }^{3-}$ response in this cyanobacterium. Alternate ALP PhoX (Ca) was found to be a low abundance protein, suggesting that PhoA (Zn, Mg) may be more environmentally relevant than PhoX.

Keywords: cyanobacteria, Synechococcus, zinc, cadmium, phosphate stress, proteome, metallothionein, alkaline phosphatase

\section{INTRODUCTION}

The marine Cyanobacteria Synechococcus and Prochlorococcus contribute between 32 and $80 \%$ of the total primary productivity in oligotrophic oceans (Goericke and Welschmeyer, 1993; Li, 1995; Liu et al., 1997; Veldhuis et al., 1997; Rocap et al., 2002) and about $50 \%$ of the fixed carbon in some oceanic regions (Zwirglmaier et al., 2007). In addition, the Marine Cluster-A group (MC-A or Synechococcus subcluster 5.1) is thought to be the dominant Synechococcus group within the euphotic zone of open ocean and coastal waters (Fuller et al., 2003). Synechococcus WH8102 is a well-studied Sargasso Sea isolate from the MCA group with an available genome sequence (Waterbury et al., 1986; Scanlan, 2003; Palenik et al., 2003). Previous culture studies examining the influences of metals on this organism showed that at low zinc $(\mathrm{Zn})$ concentrations increased cadmium $(\mathrm{Cd})$ concentrations inhibited growth, whereas this was not observed at higher Zn concentrations (Saito et al., 2003).

$\mathrm{Cd}$ and $\mathrm{Zn}$ have nutrient-like distributions in the ocean, meaning they are depleted in surface waters and increase with depth, implying that $\mathrm{Cd}$ and $\mathrm{Zn}$ are taken up by microorganisms in the surface water and remineralized at depth (Boyle et al., 1976; Bruland, 1980). Dissolved total Zn may reach concentrations up to $\sim 9 \mathrm{nM}$ at depth, whereas $\mathrm{Cd}$ may reach up to $\sim 1 \mathrm{nM}$ (Bruland, 1980, 1992). Notably, this excess of dissolved Zn over Cd is typical of deepwater ocean environments, however, this difference can decrease in surface waters as $\mathrm{Zn}$ is depleted (Sunda and Huntsman, 2000; Saito et al., 2010). Zn is important to the proper functionality of many enzymes and is thought to be an essential metal in living organisms, whereas $\mathrm{Cd}$ is only known to be used in some carbonic anhydrases of diatoms (Morel et al., 1994; Lee et al., 1995; Lane and Morel, 2000; Lane et al., 2005; Park et al., 2007; Xu et al., 2008). As a result, these metals may have different roles in different environments and organisms. $\mathrm{Zn}$ is a nutrient in the open ocean and has been suggested to influence phytoplankton diversity in the Ross Sea (Saito et al., 2010). In cyanobacteria, the $\mathrm{Zn}$ requirements appear to be very low, consistent with the idea that cyanobacteria may have evolved in a sulfidic or ferruginous ancient ocean when $\mathrm{Zn}$ was strongly complexed and of low 
bioavailability (Saito et al., 2003; Robbins et al., 2013). A coastal cyanobacterium, Synechococcus bacillaris showed no requirement for Zn (Sunda and Huntsman, 1995). In addition, low Zn abundances were shown to have little to no effect on the growth rates of the related marine cyanobacterium Prochlorococcus marinus strain MED4 (Saito et al., 2002). Notably these Zn limitation studies were conducted with replete inorganic phosphate and no added organic phosphate. Perhaps because of the low $\mathrm{Zn}$ requirement and trace metal culturing techniques required to perform such investigations, there are few studies of intracellular $\mathrm{Zn}$ homeostasis mechanisms in marine cyanobacteria (Blindauer, 2008). In terms of $\mathrm{Cd}$, it has been noticed that the dissolved $\mathrm{Cd}: \mathrm{PO}_{4}{ }^{3-}$ ratios are lower in the surface waters of iron-limited regions, implying preferential removal of Cd relative to $\mathrm{PO}_{4}{ }^{3-}$ in iron-limited waters, perhaps due to $\mathrm{Cd}$ transport through ferrous iron transporters or prior depletion of $\mathrm{Zn}$ (Cullen, 2006; Lane et al., 2009; Saito et al., 2010). As a result, the potential interactions between $\mathrm{Cd}$ and $\mathrm{Zn}$ in the ocean range from biochemical substitution in diatoms (Morel et al., 1994; Lee et al., 1995; Lane and Morel, 2000; Lane et al., 2005) to antagonistic effects in cyanobacteria.

$\mathrm{Cd}$ has been suspected to interact with $\mathrm{Zn}$ in organisms for over half a century. Early mentions of this concept stated that in certain fungi Cd cannot physiologically replace $\mathrm{Zn}$ (Goldschmidt, 1954), and recent studies have shown that Cd can restore growth in Zn-limited marine diatoms (Price and Morel, 1990; Lee and Morel, 1995; Sunda and Huntsman, 2000). In marine cyanobacteria the intracellular destination of Cd is likely metallothionein, but other possibilities exist such as low molecular weight thiols, polyphosphates or metalloenzymes like carbonic anhydrase (Cox, 2011). A connection of $\mathrm{Zn}$ and perhaps Cd to phosphate exists due to the $\mathrm{Zn}$ metalloenzyme alkaline phosphatase that is used by marine microbes in the acquisition of organic phosphate. Bacterial cells have evolved complicated mechanisms to ensure that metalloproteins contain the correct metal, but the processes are not perfect and elucidating these mechanisms may require a systems-based approach (Waldron and Robinson, 2009). In this study, by adding Cd to a Zn-scarce environment, we are exposing cells to a metal to which they are unaccustomed in order to discern cellular processing of these specific metals by observing the protein system response.

Phosphorus is an essential nutrient, utilized in the cell as part of large biomolecules (DNA, RNA, phospholipids), for chemical energy transfer (adenine triphosphate, ATP), in cellular signaling networks, and in reversible chemical modification of proteins. It is typically found at low micromolar to nanomolar concentrations in the ocean and is limiting in some regions. It composes some $2-4 \%$ dry weight of cells (Karl, 2000). Scarcity of both phosphorus and $\mathrm{Zn}$ could result in biochemically dependent colimitation, in which the uptake of organic phosphorus, is dependent upon $\mathrm{Zn}$ adequate nutrition due to its role in alkaline phosphatase (Saito et al., 2008). It has been hypothesized that $\mathrm{Zn}$ and phosphorus colimitation could occur in oligotrophic regions such as the Sargasso Sea, based on laboratory experiments with the coccolithophore Emiliania huxleyi (Shaked et al., 2006).

In this manuscript, the physiological and proteomic responses of the open ocean Synechococcus WH8102 to acute Cd exposure under varying chronic $\mathrm{Zn}$ and $\mathrm{PO}_{4}{ }^{3-}$ concentrations were examined to (1) probe $\mathrm{Zn}$ use in the organism and how it deals with an interfering metal (Cd), (2) investigate potential ecological and biogeochemical significance of $\mathrm{Cd}$ and $\mathrm{Zn}$ interactions, (3) investigate the effects of $\mathrm{Cd}$ on phosphate stress proteins and (4) investigate the influence of $\mathrm{Zn}$ on phosphate stress. Given that $\mathrm{Zn}$ is found in excess of $\mathrm{Cd}$ in oceanic habitats, reversing this relationship with short-term Cd enrichments provides opportunities to probe metal homeostasis in cyanobacteria. The proteome response in high and low concentrations of phosphate showed distinct responses in alkaline phosphatase and metallothionein with $\mathrm{Cd}$ or $\mathrm{Zn}$ suggesting that the regulatory system responds to the two metals differently ( $\mathrm{Zn}$ is currently thought to be vital at low phosphate whereas Cd is not). Alkaline phosphate and metallothionein show similar responses suggesting a $\mathrm{Zn}$ handling mechanism in which metallothionein supplies alkaline phosphatase with Zn may exist.

\section{METHODS \\ CULTURING}

Axenic cultures of Synechococcus sp. WH8102 were obtained from J. Waterbury and F. Valois (Woods Hole Oceanographic Institution) and maintained in a PRO-TM media [modified from (Saito et al., 2002)] made with 75\% oligotrophic seawater obtained from the oligotrophic South Atlantic ocean and prepared by microwave sterilization and the addition of chelexed and sterile filtered nutrients $\left[1.1 \mathrm{mM} \mathrm{NO}_{3}^{-}\right.$and $65 \mu \mathrm{M} \mathrm{PO}_{4}{ }^{3-}$ ] and ethylenediaminetetraacetic acid (EDTA)-complexed metals $\left(22.2 \mu \mathrm{M}\right.$ EDTA, $171 \mathrm{nM} \mathrm{MnCl} 2,5.7 \mathrm{nM} \mathrm{Na} 2 \mathrm{MoO}_{4}, 19 \mathrm{nM}$ $\mathrm{Na}_{2} \mathrm{SeO}_{3}, 2.22 \mu \mathrm{M} \mathrm{FeCl}_{3}, 19 \mathrm{nM} \mathrm{CoCl}_{2}, 19 \mathrm{nM} \mathrm{NiCl}_{2}$ ). The scarce $\mathrm{Zn}^{2+}$ condition had no $\mathrm{Zn}$ added whereas replete had $\mathrm{Zn}$ added to a total concentration of $10 \mathrm{nM}$, with the free concentrations estimated to be tens of picomolar $\mathrm{Zn}^{2+}$ (Saito et al., 2003). Low $\mathrm{PO}_{4}{ }^{3-}$ cultures had $1 \mu \mathrm{M} \mathrm{PO}_{4}{ }^{3-}$ added, whereas high had $65 \mu \mathrm{M}$ $\mathrm{PO}_{4}{ }^{3-}$. The ideal low concentration of $\mathrm{PO}_{4}{ }^{3-}$ for this experiment was determined in a reconnaissance study with concentrations ranging from no added $\mathrm{PO}_{4}{ }^{3-}$ to $65 \mu_{\mathrm{MPO}_{4}}{ }^{3-}$ added (Figure 1). Acute $\mathrm{Cd}$ treatments had $\mathrm{Cd}$ added to a total concentration of $10 \mathrm{nM} \mathrm{CdCl}_{2}$, with the free concentrations estimated to be $4.4 \mathrm{pM}$ $\mathrm{Cd}^{2+}$ using EDTA stability constant data from Smith and Martell (1993). The ratio of $\mathrm{Cd}^{2+}: \mathrm{Cd}_{\mathrm{TOT}}$ was calculated to be $1: 2267$. This ratio in a PRO-TM media with $11.7 \mu \mathrm{M}$ EDTA (Saito et al., 2002) was calculated to be 1:1216 (Saito et al., 2003) and 1:6026 in a media with $100 \mu \mathrm{M}$ EDTA (Sunda and Hunstman, 1998). The ratio of $\mathrm{Cd}^{2+}$ to the total of major inorganic species in a PROTM media with $11.7 \mu \mathrm{M}$ EDTA (Saito et al., 2002) was calculated to be 1:36 (Saito et al., 2003). The blank of the medium was not determined. Previous researchers doing similar trace metal culture studies have assumed background metal concentrations of 100 pM for cobalt (Sunda and Huntsman, 1995; Sunda and Hunstman, 1998; Saito et al., 2002), 900 pM for zinc (Sunda and Huntsman, 1995; Sunda and Hunstman, 1998) and 100 pM for cadmium (Sunda and Hunstman, 1998).

Cultures were grown in either $28 \mathrm{~mL}$ polycarbonate tubes or $500 \mathrm{~mL}$ polycarbonate bottles under $30 \mu \mathrm{E} \mathrm{m}^{-2} \mathrm{~s}^{-1}$ continuous white light. At mid-log phase, the four $500 \mathrm{~mL}$ cultures were split and $4.4 \mathrm{pM} \mathrm{Cd}^{2+}$ added to one of each treatment (hereafter 
$\mathrm{Cd}$ addition). The 8 resulting cultures were harvested $24 \mathrm{~h}$ later (Figure 2). Culture growth was monitored by a combination of chlorophyll $a$ and phycoerythrin fluorescence and cell counting by microscopy. All plasticware was soaked for two days in a detergent, then two weeks in $10 \% \mathrm{HCl}$ (Fisher, trace metal grade), rinsed with $\mathrm{pH} 2 \mathrm{HCl}$ and then microwave sterilized. Growth rates were calculated from the slope of the natural log of in vivo relative chlorophyll $a$ fluorescence ( $n=5$ timepoints, Figure 3). For protein samples, approximately $200 \mathrm{~mL}$ of culture were harvested by centrifugation in a Beckman J2-21M centrifuge at $18,566 \mathrm{~g}$ for $30 \mathrm{~min}$ at $4^{\circ} \mathrm{C}$, decanted, transferred into a microtube and centrifuged again at $14,000 \mathrm{~g}$ for $15 \mathrm{~min}$ at room temperature, decanted, and frozen at $-80^{\circ} \mathrm{C}$.

\section{PROTEIN EXTRACTION}

Protein was extracted from the digestion of frozen whole cell pellets. Sample tubes were kept on ice throughout the extraction process, unless otherwise noted. Cell pellets were resuspended in $500 \mu \mathrm{L}$ of ice-cold $100 \mathrm{mM}$ ammonium bicarbonate buffer solution, pH 8.0 (AMBIC). Samples were sonicated on ice using a



FIGURE 1 | Phycoerythrin fluorescence vs. time, chronic $\mathrm{PO}_{4}{ }^{3-}$ limitation reconnaissance study. Error bars are one standard deviation of triplicate $28 \mathrm{~mL}$ tubes. Note that no $\mathrm{PO}_{4}{ }^{3-}$ added treatments, both with and without $\mathrm{Zn}$ appear to have a stationary phase. $1 \mu_{\mathrm{M} \mathrm{PO}}{ }^{3-}$ treatments appear to have a brief stationary phase and then enter death phase, the $\mathrm{Zn}$ dying faster than the no $\mathrm{Zn}$. The $5 \mathrm{\mu M} \mathrm{PO}_{4}{ }^{3-}$ treatments fluoresced to a greater maximum than the $65 \mathrm{MM} \mathrm{PO}_{4}{ }^{3-}$.

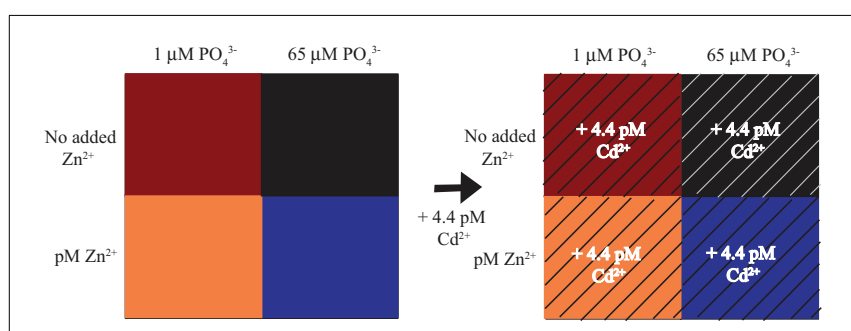

FIGURE 2 | Experimental Design. Four experimental treatments with variable $\mathrm{Zn}$ and $\mathrm{PO}_{4}{ }^{3-}$ concentrations were grown to mid-log phase, split evenly and $4.4 \mathrm{pM} \mathrm{Cd}^{2+}$ added acutely to one of the splits of each treatment.
Branson sonifier 450 for $4 \mathrm{~min}$ at $70 \%$ duty with an output level of 3 , allowed a $5 \mathrm{~min}$ pause, then sonicated for another $4 \mathrm{~min}$. Samples were then centrifuged at $4^{\circ} \mathrm{C}$ at $14,000 \mathrm{~g}$ for $35 \mathrm{~min}$. $200 \mu \mathrm{L}$ of supernatant were precipitated overnight with $800 \mu \mathrm{L}$ of $-20^{\circ} \mathrm{C}$ acetone.

Acetone-precipitated samples were centrifuged at $4^{\circ} \mathrm{C}$ at $14,000 \mathrm{~g}$ for $30 \mathrm{~min}$ and decanted. One hundred $\mu \mathrm{L}$ of freshly made $7.5 \mathrm{M}$ urea in AMBIC and $25 \mu \mathrm{L}$ of AMBIC were added to the acetone-precipitated pellet. Samples were incubated for approximately $15 \mathrm{~min}$ at room temperature with periodic vortexing then resuspended by incubation for $5 \mathrm{~min}$ at $95^{\circ} \mathrm{C}$. A $100 \mu \mathrm{L}$ aliquot was removed and $5 \mu \mathrm{L}$ of $200 \mathrm{mM}$ dithiothreitol (DTT) in AMBIC were added and incubated for $1 \mathrm{~h}$ at $56^{\circ} \mathrm{C}$, shaken at $400 \mathrm{rpm}$. The samples were vortexed and centrifuged at $14,000 \mathrm{~g}$ for $2 \mathrm{~min}$. Twenty $\mu \mathrm{L}$ of $200 \mathrm{mM}$ iodacetamide in AMBIC were added and incubated for $1 \mathrm{~h}$ at room temperature in the dark, shaken at $400 \mathrm{rpm} .20 \mu \mathrm{L}$ of $200 \mathrm{mM}$ DTT in AMBIC were added, mixed, centrifuged for $2 \mathrm{~min}$ as above, and incubated for $1 \mathrm{~h}$ at room temperature, shaken at $400 \mathrm{rpm}$. After incubation, samples were centrifuged for $2 \mathrm{~min}$ as above. Total protein yield was assayed using the Biorad DC Protein Assay. Trypsin (Promega) was reconstituted in $500 \mu \mathrm{L}$ of $50 \mathrm{mM}$ acetic acid and added in a trypsin to protein ratio of $1: 50$. The samples were mixed, vortexed, centrifuged for $2 \mathrm{~min}$ as above, and incubated for approximately $16 \mathrm{~h}$ at $37^{\circ} \mathrm{C}$, shaken at $400 \mathrm{rpm}$.

After trypsin digestion, samples were vortexed, centrifuged for $2 \mathrm{~min}$, and $20 \mu \mathrm{L}$ of LC-MS grade glacial acetic acid added. Samples were evaporated by speed vacuum for approximately $3 \mathrm{~h}$ to a final volume of approximately $600 \mu \mathrm{L}$. The samples were centrifuged at 14,000 g for 30 minutes and the supernatants collected. Four micrograms of protein were injected for LC-MS.

\section{LIQUID CHROMATOGRAPHY-MASS SPECTROMETRY (LC-MS)}

The digests were analyzed by LC-MS using a Microhm Paradigm MS4 HPLC system with reverse phase chromatography, Thermo LTQ ion trap mass spectrometer and Microhm ADVANCE source $[2 \mu \mathrm{L} / \mathrm{min}$ flow rate; reversed phase Magic C18 AQ column, $0.2 \times 150 \mathrm{~mm}, 3 \mu \mathrm{m}$ particle size, $200 \AA$ poresize; $345 \mathrm{~min}$ runs; hyperbolic gradient of water to acetonitrile (each containing $0.1 \%$ formic acid)]. Each digest was injected three times for a total of 24 mass spectrometry runs; only two runs from each treatment were analyzed. Mass spectra were processed by SEQUEST and PeptideProphet with a fragment tolerance of $1.0 \mathrm{Da}$ (monoisotopic), parent tolerance of $2.0 \mathrm{Da}$ (monoisotopic, fixed modification of +57 on $\mathrm{C}$ (carbamidomethyl), variable modification of +16 on $\mathrm{M}$ (oxidation) and a maximum of 2 missed trypsin cleavages using a database including reversed proteins and common contaminants.

Spectral counts of 16 files were compiled in Scaffold 3 Proteome Software with a peptide false discovery rate of $1.9 \%$, minimum peptide and protein tolerances of 95 and $99 \%$, respectively, with a minimum of 2 peptides (Peng et al., 2003; Zhang et al., 2006). A spectral count is the number of times a particular peptide from a protein is sampled during an MS/MS experiment and the normalized spectral count is indicative of protein relative abundance. Protein functions were assigned manually using 

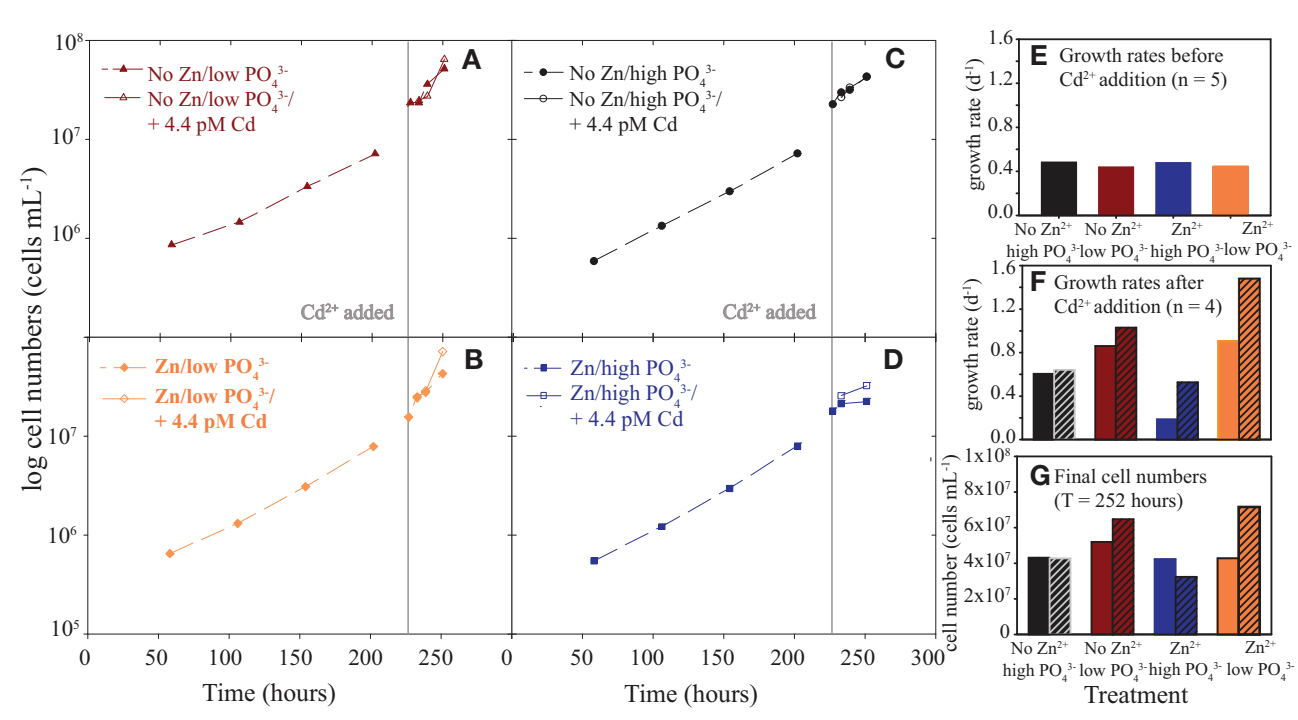

FIGURE 3 | Cell numbers vs. time, growth rates, and final cell numbers. (A) no $\mathrm{Zn} / \mathrm{low} \mathrm{PO}_{4}{ }^{3-}$ with and without short-term Cd addition, (B) $\mathrm{Zn} / \mathrm{low}$ $\mathrm{PO}_{4}{ }^{3-}$ with and without short-term Cd addition, (C) no $\mathrm{Zn} /$ high $\mathrm{PO}_{4}{ }^{3-}$ with and without short-term Cd addition, (D) $\mathrm{Zn} /$ high $\mathrm{PO}_{4}{ }^{3-}$ with and without short-term Cd addition, (E) growth rates, (F) growth rates in the $24 \mathrm{~h}$ after $\mathrm{Cd}$ addition until harvest and (G) final cell numbers at harvest. Vertical lines mark time of $\mathrm{Cd}$ addition. Note that final cell numbers are higher in low than high phosphate. n, number of timepoints. the Kyoto Encyclopedia of Genes and Genomes (KEGG) unless otherwise noted.

\section{PAIRWISE ANALYSES AND FISHER'S EXACT TEST}

Proteins were considered differentially abundant in the pairwise analyses if the average spectral count value of one of the pairs was equal to or greater than five and the pair of proteins different by two-fold or more. Use of Fisher's Exact Test (Zhang et al., 2006) confirms that most proteins are different in abundance using these stringencies, excepting a few proteins with five spectral counts. The two-fold or more differentially abundant proteins with low spectral counts remain in the tables, but are considered tenuous in analysis. The results of Fisher's Exact Test also conclude that more proteins are statistically different in abundance than the greater than or equal to two-fold analysis alone. This is because a smaller fold difference in a greater value is statistically different, thus proteins with higher spectral counts that are different by less than two-fold are differentially abundant.

\section{RESULTS}

\section{PHYSIOLOGICAL DATA}

Growth limiting $\mathrm{PO}_{4}{ }^{3-}$ concentrations for Synechococcus WH8102 were determined in a reconnaissance experiment to occur at no added and $1 \mu \mathrm{MPO}_{4}{ }^{3-}$ (Figure 1). No added $\mathrm{PO}_{4}{ }^{3-}$ treatments had very low biomass and so $1 \mu \mathrm{M}$ was chosen for the low $\mathrm{PO}_{4}{ }^{3-}$ treatment and $65 \mu \mathrm{M}$ for the high $\mathrm{PO}_{4}{ }^{3-}$ in subsequent proteomic experiments. This slightly contrasts the transcriptome study of Tetu et al. (2009), where Synechococcus WH8102 was $\mathrm{PO}_{4}{ }^{3-}$ stressed at $5 \mu \mathrm{M}$.

Synechococcus WH8102 was grown in a matrix of $\mathrm{Zn}$ ( $\mathrm{Zn}$ or no $\mathrm{Zn}$ hereafter, no $\mathrm{Zn}$ treatment also referred to as "scarce") and $\mathrm{PO}_{4}{ }^{3-}$ conditions to examine the potential interactions (Figure 2). In late log phase, cultures were split and an environmentally relevant amount of $\mathrm{Cd}$ was added to one split (4.4 $\mathrm{pM} \mathrm{Cd}^{2+}, 10 \mathrm{nM} \mathrm{Cd}_{\mathrm{TOT}}$ ) to test the $\mathrm{Cd}$ response. Responses were monitored by phycoerythrin and chlorophyll $a$ in vivo fluorescence and cell counts every $48 \mathrm{~h}$ during the 11-day experiment and four times in the last $24 \mathrm{~h}$ for the short-term $\mathrm{Cd}$ addition experiment (cell abundances in Figure 3, fluorescence data in Cox, 2011). These growth curves revealed four main observations: First, growth rates of the $\mathrm{Zn} / \mathrm{PO}_{4}{ }^{3-}$ matrix prior to Cd addition were similar, the low $\mathrm{PO}_{4}{ }^{3-}$ treatments with slightly lower growth rates (Figure $3 \mathrm{E}$ ). Growth rates were calculated using cell abundances (Figures 3A-D), rather then fluorescence (Figure 1). Second, the $\mathrm{Zn} /$ high $\mathrm{PO}_{4}{ }^{3-}$ treatment appeared to enter a stable stationary phase relative to other treatments (Figures 3D,F). Third, low $\mathrm{PO}_{4}{ }^{3-}$ treatments showed increased instantaneous growth rates relative to high $\mathrm{PO}_{4}{ }^{3-}$ during the final $24 \mathrm{~h}$ of the experiment (Figure 3F). Physical perturbation of the cultures by splitting them may have caused a different response in the low and high $\mathrm{PO}_{4}{ }^{3-}$ treatments. Last, Cd addition increased instantaneous growth rates even further above the low $\mathrm{PO}_{4}{ }^{3-}$ and $\mathrm{Zn}$ treatments (Figure 3F). Final cell numbers at harvest for protein biomass were similar for most treatments, but showed slightly elevated cell numbers for two treatments, no $\mathrm{Zn} /$ low $\mathrm{PO}_{4}{ }^{3-}$ /short-term $\mathrm{Cd}$ and $\mathrm{Zn} /$ low $\mathrm{PO}_{4}{ }^{3-}$ /short-term Cd (Figure 3G).

\section{GLOBAL PROTEOMIC DATA}

Analysis resulted in the identification of 483 proteins and 3947 unique peptides from 62,264 mass spectra over 16 LC-MS injections, 8 treatments injected in duplicate (Data Sheet 1). Using the peptide prophet algorithm in Scaffold 3, 95\% peptide minimum confidence level, $99.9 \%$ protein minimum confidence level and a minimum of 2 peptides per protein identification resulted in a $1.9 \%$ peptide false discovery rate (Peng et al., 2003; Zhang 
et al., 2006) (Data Sheet 1). This experiment identified 24\% of the 2519 possible proteins present in the genome of WH8102. Using the same conditions mentioned above but with a more stringent minimum of 3 peptides per protein identification resulted in 420 protein identifications with a $0.9 \%$ peptide false discovery rate. Seventy-one proteins showed differences in protein abundances in at least two treatments using a minimum difference of 7 spectral counts and a threshold of 7 spectral counts, based on technical replicates of each of the 8 treatments.

Both cluster analysis (Figure 4; Datasheet 1; Eisen et al., 1998) and pairwise comparisons between experimental treatments foremost reveal $\mathrm{PO}_{4}{ }^{3-}$ stress effects, and next $\mathrm{Cd}$ and $\mathrm{Zn}$ effects (Figure 5; Tables 1-3; Supplementary Tables 1A-K). Each column represents a number of proteins that are at least two-fold different in abundance when a single condition is varied and the protein bars are coded by function (Figure 5). In these pairwise proteome comparisons, three observations can be made. First, the no $\mathrm{Zn} /$ low $\mathrm{PO}_{4}{ }^{3-}$ treatment had the greatest number of proteins that were two-fold different in abundance among all pairwise comparisons (55 in Figure 5A, 32 in Figure 5B and 31 in Figure 5C). In contrast, the no $\mathrm{Zn} /$ high $\mathrm{PO}_{4}{ }^{3-}$ treatment had 55 different proteins in Figure 5A [same number because directly compared to the low $\mathrm{PO}_{4}{ }^{3-}$ ], 10 in Figure 5B and 16 in Figure 5C. Second, Cd addition caused a greater change in the number of two-fold different proteins when $\mathrm{Zn}$ was absent (Figure 5B). The presence of $\mathrm{Zn}$ caused a smaller change in the total number of proteins of two-fold difference when $\mathrm{Cd}$ was added [42 with no $\mathrm{Zn}$, both high and low $\mathrm{PO}_{4}{ }^{3-}$ to 11 proteins in the presence of $\mathrm{Zn}$, both high and low $\mathrm{PO}_{4}{ }^{3-}$; Figure 5B]. Third, short-term $\mathrm{Cd}$ addition under both low and high $\mathrm{PO}_{4}{ }^{3-}$ conditions had fewer proteins of two-fold difference than in the presence or absence of $\mathrm{Zn}$, suggestive of possible $\mathrm{Cd}$ alleviation of $\mathrm{Zn}$ deprivation (Figure 5C). These observations imply the $\mathrm{Zn}$ deprivation combined with $\mathrm{PO}_{4}{ }^{3-}$ stress causes the greatest number of proteins to be differentially abundant, the proteome responds more with $\mathrm{Cd}$ addition without added $\mathrm{Zn}$ in the media, and $\mathrm{Zn}$ alleviates $\mathrm{Cd}$ addition effects at both high and low $\mathrm{PO}_{4}{ }^{3-}$.

The proteome response to high and low $\mathrm{PO}_{4}{ }^{3-}$ (in the $\mathrm{Zn}$ treatments) was similar to the transcriptome results by Tetu et al. (2009), which used the same Synechococcus strain (Figure 6). Eighteen total proteins were two-fold or more differentially abundant (with a spectral count threshold of at least five) between 1 and $65 \mu \mathrm{M} \mathrm{PO}_{4}{ }^{3-}$ treatments, (Table 1). Eight proteins were more abundant in the $1 \mu \mathrm{M} \mathrm{PO}_{4}{ }^{3-}$ treatment, including 6 proteins found to be similarly differentially expressed in the transcriptome (Figure 6, starred in Table 1). These 6 proteins include a putative alkaline phosphatase and a phosphate binding protein component of an ABC transporter (PstS). Also of note is a bacterial metallothionein that was not observed in the microarray experiment. The metallothionein, alkaline phosphatase, and phosphate transporter also show higher relative abundances at low $\mathrm{PO}_{4}{ }^{3-}$ with increased $\mathrm{Zn}$ abundance (Figure 7). Six of the ten proteins more abundant in the $65 \mu \mathrm{M}$ $\mathrm{PO}_{4}{ }^{3-}$ treatments were ribosomal proteins and one of these was downregulated as a transcript (50S ribosomal protein L18, Table 1).
In addition to $\mathrm{PO}_{4}{ }^{3-}$ effects alone, we examined the $\mathrm{PO}_{4}{ }^{3-}$ response with and without added $\mathrm{Zn}$. Table 2 lists the 55 proteins with differential responses at low $\mathrm{PO}_{4}{ }^{3-}$. Sixteen proteins were more abundant in the low $\mathrm{PO}_{4}{ }^{3-}$ treatment, including five hypothetical proteins and two proteins involved in photosynthesis. Under low $\mathrm{Zn}$ no proteins showed abundance trends similar to gene expression in the microarray experiment. Note that metallothionein, alkaline phosphatase and the ABC transporter, phosphate substrate binding protein were less abundant in the low $\mathrm{PO}_{4}{ }^{3-}$ without $\mathrm{Zn}$ than with $\mathrm{Zn}$ (Figure 7).

We also examined the proteome $\mathrm{PO}_{4}{ }^{3-}$ response in the presence and absence of $\mathrm{Zn}$ with the added interaction of $\mathrm{Cd} .17$ proteins were two-fold or more differentially abundant in the presence of $\mathrm{Zn}, 12$ proteins with no added $\mathrm{Zn}$ (Supplementary Tables $1 \mathrm{~A}, \mathrm{~B})$. Nine proteins were more abundant in the $\mathrm{Zn} / \mathrm{low}$ $\mathrm{PO}_{4}{ }^{3-}$ /short-term $\mathrm{Cd}$ treatment, including phosphate stress proteins. Eight proteins were more abundant in the $\mathrm{Zn} /$ high $\mathrm{PO}_{4}{ }^{3-}$ /short-term $\mathrm{Cd}$ treatment, including three related to the phycobilisomes and two ribosomal proteins. Six of the eight proteins more abundant in the no $\mathrm{Zn} /$ high $\mathrm{PO}_{4}{ }^{3-}$ /short-term $\mathrm{Cd}$ treatment were involved in photosynthesis.

Cd-specific effects were discerned by examining pairwise protein comparisons (Figure 5). Cd effects were expected to be more pronounced with no added $\mathrm{Zn}$. In the no $\mathrm{Zn} /$ high $\mathrm{PO}_{4}{ }^{3-} /$ shortterm $\mathrm{Cd}^{2+}$ compared to no $\mathrm{Cd}^{2+}$ added treatments, 10 proteins were two-fold or more differentially abundant (Table 3). Five proteins were more abundant in the no $\mathrm{Zn} /$ high $\mathrm{PO}_{4}{ }^{3-}$ /shortterm $\mathrm{Cd}^{2+}$ treatment including three unknown proteins and one involved in photosystem II (Figure 8; Table 3). Five proteins were more abundant in the no $\mathrm{Zn} /$ high $\mathrm{PO}_{4}{ }^{3-} /$ no added $\mathrm{Cd}^{2+}$ treatment (Figure 9; Table 3). In addition, 10 proteins significantly different by Fisher's Exact Test are included in Figure 8 (five involved in photosynthesis) and 3 (two involved in photosynthesis) in Figure 9 (Supplementary Table 1C). The other three $\mathrm{Zn}$ and $\mathrm{PO}_{4}{ }^{3-}$ conditions for cadmium comparison showed some differences upon $\mathrm{Cd}$ addition. At high $\mathrm{PO}_{4}{ }^{3-}$, short-term $\mathrm{Cd}$ addition in the presence of $\mathrm{Zn}$ caused 4 proteins to be differentially abundant (Supplementary Table 1D). At low $\mathrm{PO}_{4}{ }^{3-}$ with no $\mathrm{Zn}, 32$ proteins were differentially abundant, whereas with added Zn, only 7 (Supplementary Tables 1E,F).

Proteins with differential abundances with respect to $\mathrm{Zn}$ are listed in Supplementary Tables 1G-J. Among those listed are proteins involved in many cellular processes, ranging from photosynthesis to lipid metabolism. Notable were four proteins more abundant in the $\mathrm{Zn} /$ low $\mathrm{PO}_{4}{ }^{3-}$ /short-term $\mathrm{Cd}^{2+}$ treatment compared to the no $\mathrm{Zn} /$ low $\mathrm{PO}_{4}{ }^{3-}$ /short-term $\mathrm{Cd}^{2+}$, including SYNW0359 bacterial metallothionein and SYNW2391 putative alkaline phosphatase (Figure 7).

Comparing the proteomic response of the presence of either $\mathrm{Cd}$ or $\mathrm{Zn}$ at high $\mathrm{PO}_{4}{ }^{3-}$ queried if $\mathrm{Cd}$ could potentially "replace" $\mathrm{Zn}$ (Figure 2 - black/hatched to blue). In the no $\mathrm{Zn} /$ high $\mathrm{PO}_{4}{ }^{3-}$ /short-term $\mathrm{Cd}^{2+}$ compared to $\mathrm{Zn} /$ high $\mathrm{PO}_{4}{ }^{3-}$ treatments, 8 proteins were two-fold or more differentially abundant (Supplementary Table $1 \mathrm{~K}$ ). Seven proteins were more abundant in the no $\mathrm{Zn} /$ high $\mathrm{PO}_{4}{ }^{3} /$ short-term $\mathrm{Cd}^{2+}$, including four proteins involved in photosynthesis, a cell surface protein required for swimming motility (SwmA) and a possible outer membrane 


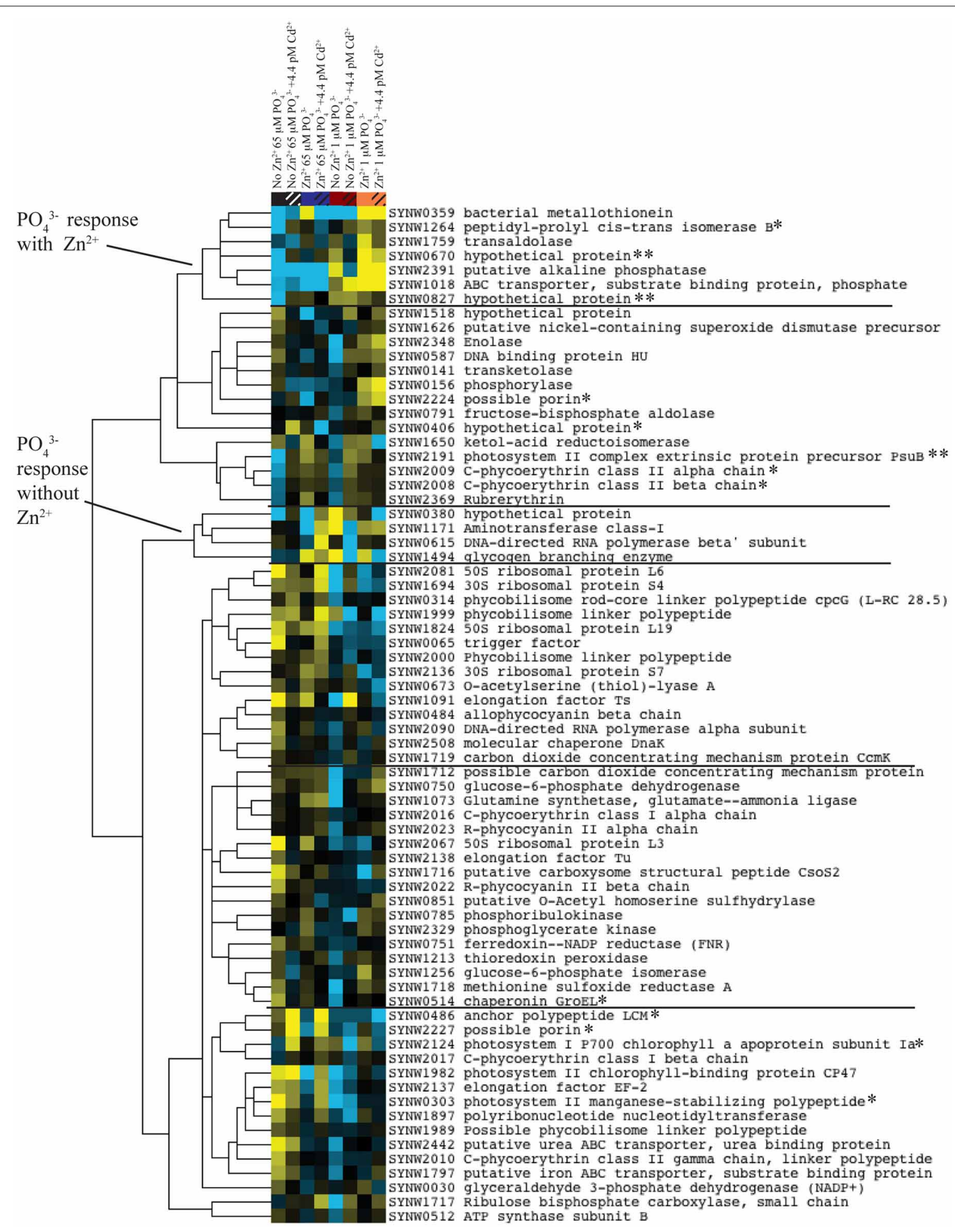

FIGURE 4 | Cluster analysis of relative protein abundances. no $\mathrm{Zn} / 65 \mu \mathrm{MPO}_{4}{ }^{3-}, \mathrm{Zn} / 65 \mu \mathrm{MPO}_{4}{ }^{3-}$, no $\mathrm{Zn} / 1 \mu \mathrm{M} \mathrm{PO}_{4}{ }^{3-}, \mathrm{Zn} / 1 \mu \mathrm{M} \mathrm{PO}{ }^{3-}$ and these four chronic treatments with short term $4.4 \mathrm{pM} \mathrm{Cd}^{2+}$ added. The four low $\mathrm{PO}_{4}{ }^{3-}$ treatments are on the right and replete, and high $\mathrm{PO}_{4}{ }^{3-}$ on the left. There are 71 proteins. Protein relative abundances are averages of duplicates, have at least 7 counts, and are different by a value of 7. Data are log transformed, centered, and clustered by Kendall's Tau, centroid linkage. Yellow, more abundant; Blue, less abundant; *, statistically different by Fisher's Exact Test between the no Zn/high $\mathrm{PO}_{4}{ }^{3-}$ and the no $\mathrm{Zn} /$ high $\mathrm{PO}_{4}{ }^{3-}$ /short-term $\mathrm{Cd}$; ${ }^{* *}$, differentially abundant by two-fold or greater and statistically different by Fisher's Exact Test between the no $\mathrm{Zn} /$ high $\mathrm{PO}_{4}{ }^{3-}$ and the no $\mathrm{Zn} /$ high $\mathrm{PO}_{4}{ }^{3-}$ /short-term Cd. 


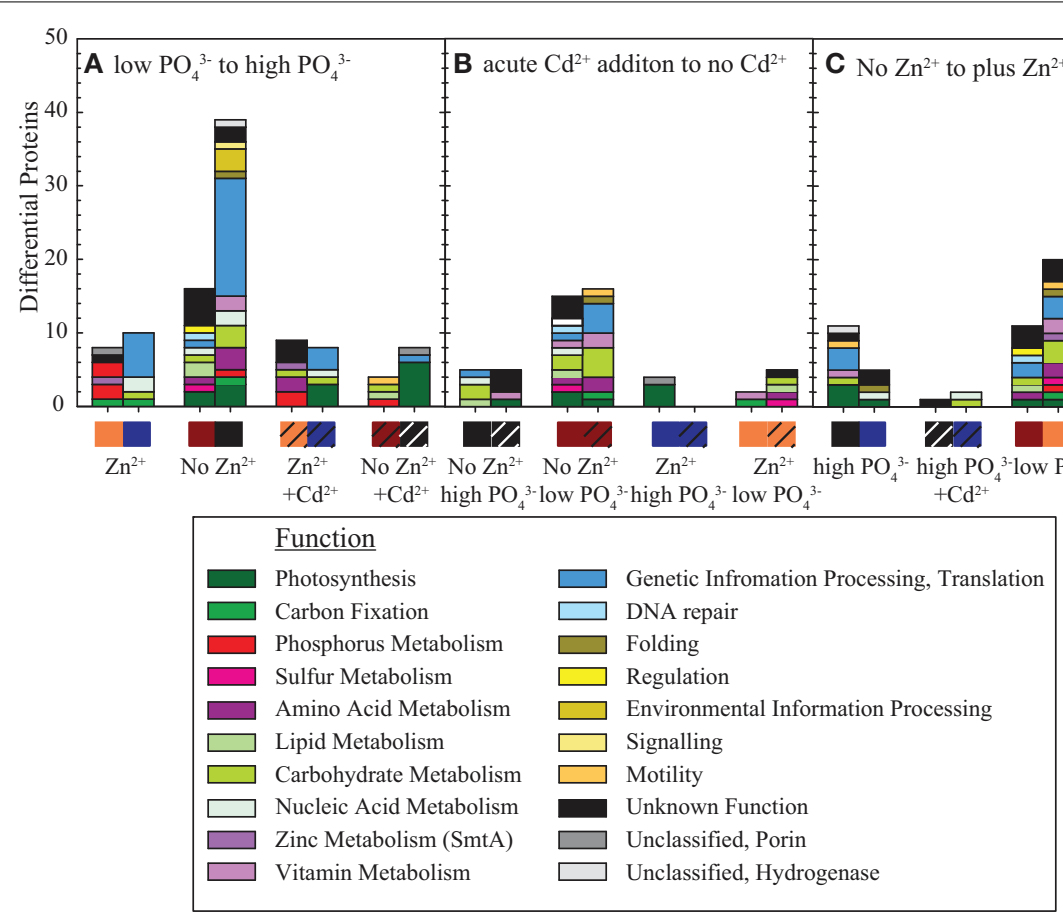

FIGURE 5 | Number of proteins two-fold or more abundant in pairwise comparisons, with other matix treatments equivalent (color bar on $x$-axis corresponds with Figure 2 design), with protein bars colored by KEGG function. (A) Proteins more abundant with scarce $\mathrm{PO}_{4}{ }^{3-}$ relative to replete conditions and vice versa (right and left bars, respectively).

(B) Proteins more abundant with short-term $\mathrm{Cd}$ addition relative to no $\mathrm{Cd}$ added and vice versa (right and left bars, respectively). (C) Proteins more abundant with scarce $\mathrm{Zn}$ relative to replete conditions and vice versa (left and right bars, respectively). Comparison of (A-C) shows that the combination of $\mathrm{Zn}$ and $\mathrm{PO}_{4}{ }^{3-}$ scarcity causes the greatest number of proteins to be differentially abundant. (B) shows that the presence of $\mathrm{Zn}$ causes less change in number of proteins when $\mathrm{Cd}$ is added. Functions and abundances for each protein are in Tables 1-3 and Supplementary Tables $1 \mathrm{~A}, \mathrm{~B}$, and $\mathrm{D}-\mathrm{J}$. associated porin with unknown function. Aconitate hydratase, involved in carbohydrate metabolism, the TCA cycle, energy metabolism, and the reductive carboxylate cycle was more abundant in the $\mathrm{Zn} /$ high $\mathrm{PO}_{4}{ }^{3-}$ treatment.

\section{DISCUSSION}

We examined the interactive influences of $\mathrm{PO}_{4}{ }^{3-}, \mathrm{Zn}$, and $\mathrm{Cd}$ on the proteome of Synechococcus WH8102. Three variables in the experimental design [long-term $\mathrm{PO}_{4}{ }^{3-}$ and $\mathrm{Zn}$ limitation and short-term Cd additions] and the dense nature of proteomic datasets yielded complex results as described in Results and Data Tables. Nevertheless, four main observations arose from these combined experiments. First, $\mathrm{PO}_{4}{ }^{3-}$ limitation had the largest effect on the proteome and showed numerous commonalities to a prior $\mathrm{PO}_{4}{ }^{3-}$ limitation transcriptome study (Tetu et al., 2009). Second, low $\mathrm{Zn}$ availability had an effect on the $\mathrm{PO}_{4}{ }^{3-}$ response, implying a critical role for this micronutrient in the $\mathrm{PO}_{4}{ }^{3-}$ response system. Third, metallothionein covaried with $\mathrm{PO}_{4}{ }^{3-}$ stress-associated proteins, implying a role in metal homeostasis and perhaps in supplying metals for metalloproteins such as alkaline phosphatase. And fourth, short-term $\mathrm{Cd}$ addition incubations were found to have the greatest influence on the proteome at low $\mathrm{PO}_{4}{ }^{3-}$ and $\mathrm{Zn}$, compared to under both replete $\mathrm{PO}_{4}{ }^{3-}$ and $\mathrm{Zn}$, implying an inability to confront $\mathrm{Cd} / \mathrm{Zn}$ imbalance. A number of other intriguing details were observed during these experiments including different relative abundance levels of alkaline phosphatase isoforms and many hypothetical proteins identified. These findings will be expanded upon in the following sections.

\section{PHOSPHATE AND ZINC INFLUENCES ON PROTEOME}

The long-term $\mathrm{PO}_{4}{ }^{3-}$ and $\mathrm{Zn}$ limitation matrix experiments allowed us to examine the influences of nutrient scarcity, both independently and synergistically. As described in Results, $\mathrm{PO}_{4}{ }^{3-}$ appeared to cause the largest difference in this $\mathrm{Cd}-\mathrm{Zn}-\mathrm{PO}_{4}{ }^{3-}$ interaction experiment (Figures 4, 5). The proteome and transcriptome showed similarity in responses (Figure 6; Tables 12). Tetu et al. (2009) identified 36 genes as having increased transcript expression under $\mathrm{PO}_{4}{ }^{3-}$ stress $\left[\mathrm{PO}_{4}{ }^{3-}\right.$ limitation was observed at $5 \mu \mathrm{M} \mathrm{PO}_{4}{ }^{3-}$ with replete at $87 \mu \mathrm{M} \mathrm{PO}_{4}{ }^{3-}$ in their study]. We identified 13 of those genes as proteins in the two $\mathrm{PO}_{4}{ }^{3-}$ treatments with $\mathrm{Zn}$ (Figure 6). Six of these proteins were at least two-fold more abundant in the low $\mathrm{PO}_{4}{ }^{3-}$ treatment (Figure 6). This means that we identified as proteins $36 \%$ of the genes upregulated in the transcriptome (13 proteins of 36 transcripts) with $17 \%$ (6 proteins of 36 transcripts) also being comparable to strongly upregulated in the transcriptome (Figure 6). This coherence between the transcriptome and proteome under $\mathrm{PO}_{4}{ }^{3-}$ limiting conditions has also been observed in two eukaryotic phytoplankters, Aureococcus anophagefferens 
Table 1 | Relative protein abundances between low and high phosphate treatments for proteins two-fold or greater differentially abundant (1 $\mu \mathrm{M} \mathrm{PO}_{4}{ }^{3-}$ and $65 \mu \mathrm{M} \mathrm{PO}_{4}{ }^{3-}$, replete $\mathrm{Zn}$ for both).

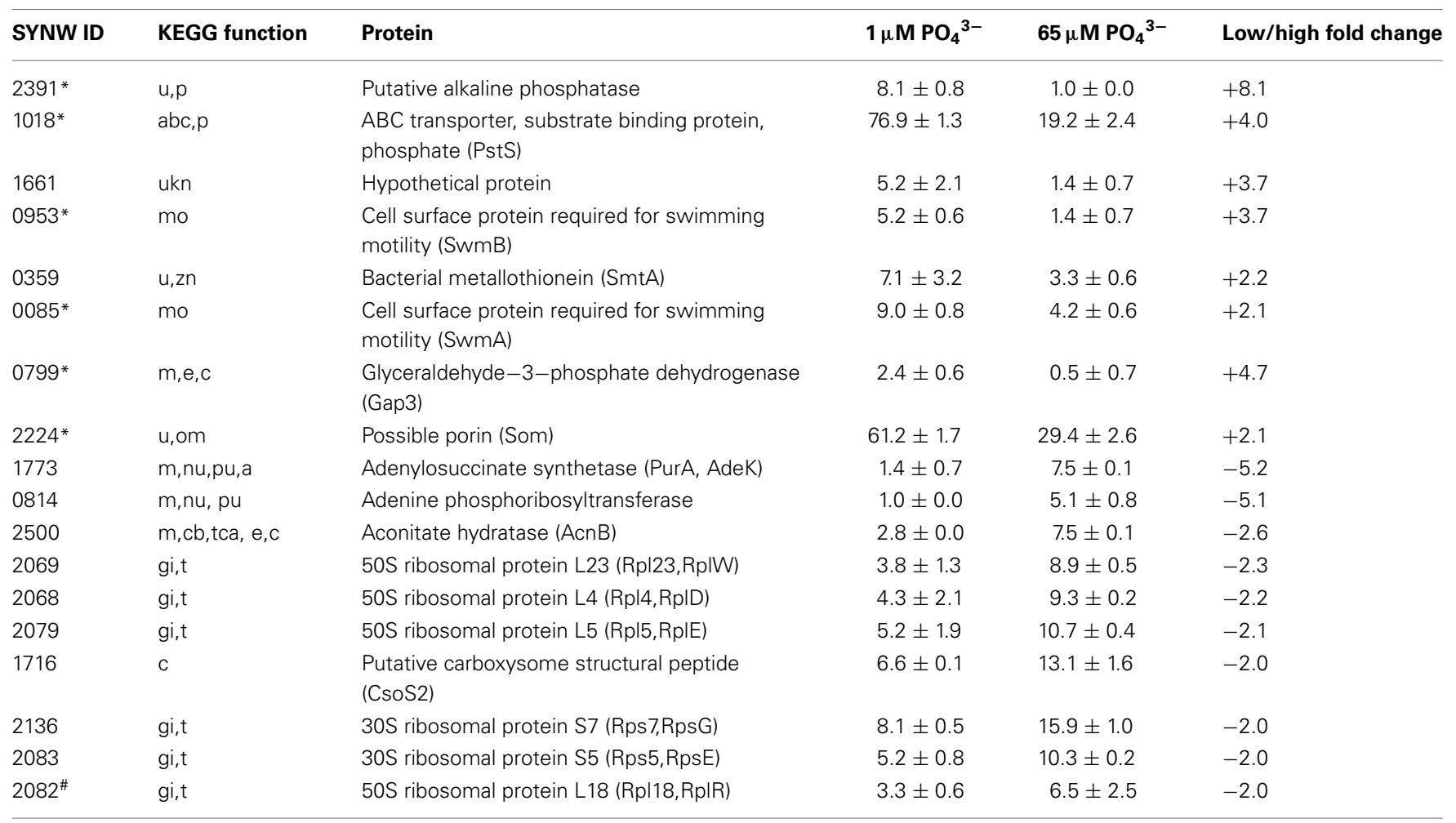

Units are spectral counts.

${ }^{*}$ Corresponding transcript identified in Tetu et al. (2009) as strongly upregulated under early P-stress [5 $\left.\mu \mathrm{MPO}{ }^{3-}\right]$; ${ }^{*}$ Corresponding transcript identified in Tetu et al. (2009) as strongly downregulated under early P-stress $\left[5 \mu \mathrm{MPO}_{4}{ }^{3-}\right.$ ]; u, unclassified; p, phosphorus metabolism; abc, ABC transporter; ukn, unknown; mo, motility; zn, zinc metabolism; m, metabolism; e, energy metabolism; c, carbon fixation; om, outer membrane protein; nu, nucleic acid metabolism; pu, purine metabolism; a, amino acid metabolism; cb, carbohydrate metabolism; tca, citrate cycle; gi, genetic information processing; $t$, translation.

and Thalassiosira pseudonana (Wurch et al., 2011; Dyhrman et al., 2012), suggesting that adaptive responses to $\mathrm{PO}_{4}{ }^{3-}$ stress and proteome/transcriptome coordination are common among marine phytoplankton. Moreover, since observations of coordination between the transcriptome and proteome have thus far been relatively recent in the literature, this study contributes to the notion that the scalable cellular capability for $\mathrm{PO}_{4}{ }^{3-}$ stress contributes to the coordination we have observed thus far amongst these three distinct marine microbes. In particular, the alkaline phosphatase (PhoA, SYNW2391), a protein that requires a metal cofactor (identified as $\mathrm{Zn}$ in model organisms), and the phosphate binding protein (PstS, SYNW1019) were identified as more abundant in both the proteome and transcriptome under $\mathrm{PO}_{4}{ }^{3-}$ stress. In addition, among the 20 proteins with increased abundance under $\mathrm{PO}_{4}{ }^{3-}$ limitation were bacterial metallothionein $(\mathrm{SmtA})$, a cell surface protein required for swimming mobility (SwmB), and three hypothetical proteins (SYNW0128, SYNW0160 and SYNW1661), suggesting that increased acquisition capability, motility, and the other proteins are also important to phosphate limitation. These observations may be related to the use of culture medium that closely resembles the metal micronutrient conditions of the open ocean.
Less overlap was observed between the transcriptome and the proteome for downregulated transcripts. Of the 23 transcripts observed strongly downregulated (greater than or equal to two-fold less) in the transcriptome study only 3 were identified as proteins, two ribosomal proteins and a conserved hypothetical protein. Of these three, only one was two-fold less in abundance (Table 1). One might expect less overlap in protein abundances from downregulated transcripts because as less protein is made detection becomes more difficult under the stringent identification parameters used here.

It is interesting to note that four of the mentioned $\mathrm{PO}_{4}{ }^{3-}$ acquisition genes, in addition to others, increased in expression in a microarray experiment when WH8102 was grown with Vibrio parahaemolyticus, a model heterotroph (Tai et al., 2009). This information combined with results from previous protein experiments in which these $\mathrm{PO}_{4}{ }^{3-}$ acquisition genes were more abundant with short-term Cd addition in WH8102 stationary phase cultures (Cox and Saito, unpublished data), suggests that the $\mathrm{PO}_{4}{ }^{3-}$ response may ultimately be triggered by many factors, including limitation experienced as a culture ages. The techniques used in this study could be applied to multi-organism experiments. 
Table 2 | Relative protein abundances between low and high phosphate treatments for proteins two-fold or greater differentially abundant $\left(1 \mu \mathrm{M} \mathrm{PO}_{4}{ }^{3-}\right.$ and $65 \mu \mathrm{M} \mathrm{PO}_{4}{ }^{3-}$, scarce $\mathrm{Zn}$ for both).




Table 2 | Continued



Units are spectral counts.

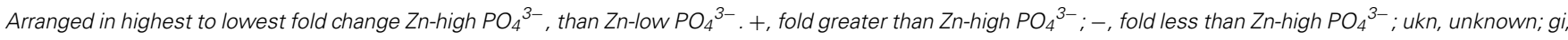
genetic information processing; re, DNA replication and repair; $m$, metabolism; cb, carbohydrate metabolism; as, amino sugar metabolism; rg, regulatory function; t, translation; nu, nucleic acid metabolism; py, pyrimidine metabolism; a, amino acid metabolism; l, lipid metabolism; ps, photosynthesis; abc, ABC transporter; $s$, sulfur metabolism; v, vitamin metabolism; po, porphyrin metabolism; chl, chlorophyll metabolism; tca, citrate cycle; e, energy metabolism; c, carbon fixation; g, glutathione metabolism; ei, environmental information processing; si, signaling; $p$, phosphorus metabolism; $f$, protein folding; pu, purine biosynthesis; $n$, nitrogen metabolism.

Table 3 | Relative protein abundances between added (+ $\left.4.4 \mathrm{pM} \mathrm{Cd}^{2+}\right)$ and no added Cd treatments for proteins two-fold or greater differentially abundant (phosphate replete and scarce $\mathrm{Zn}$ for both).

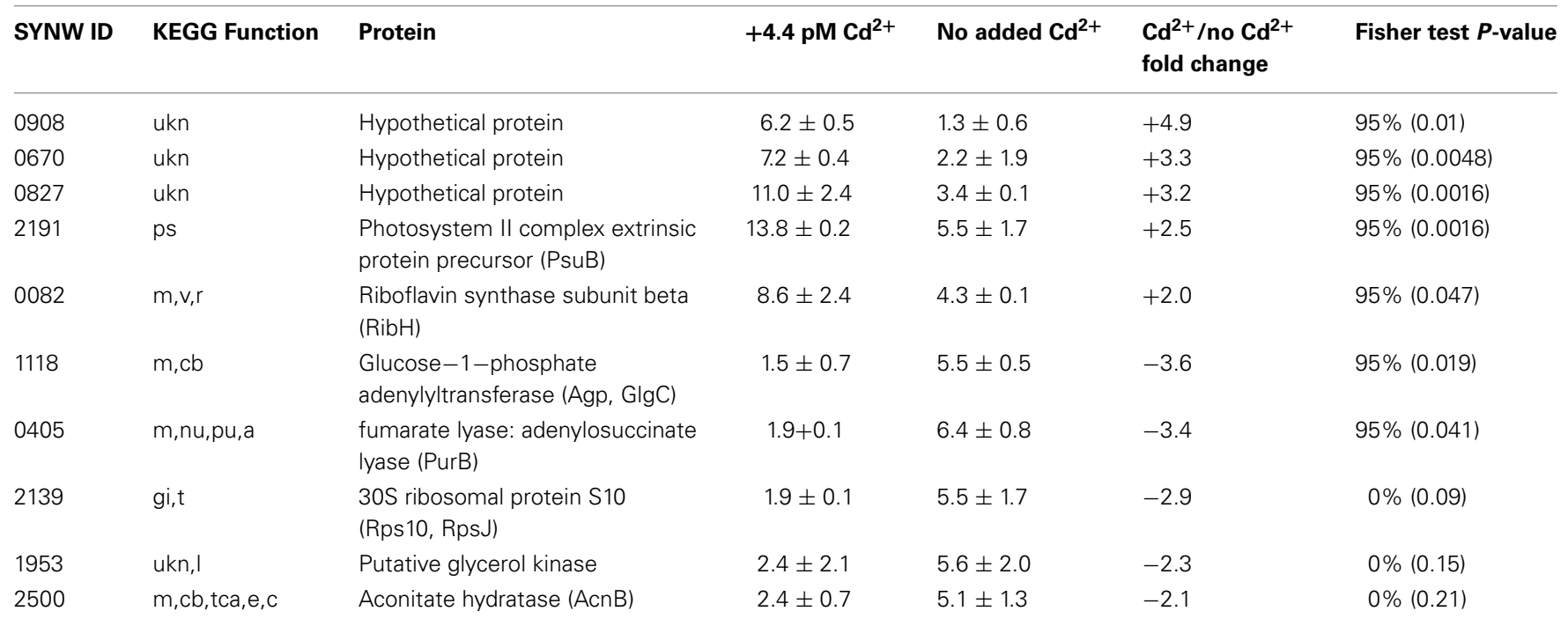

Units are spectral counts.

Arranged in highest to lowest fold change $4.4 \mathrm{pM} \mathrm{Cd}^{2+}$ vs. control (no Zn and no added Cd). +, fold greater than control; -, fold less than control; ukn, unknown; ps, photosynthesis; m, metabolism; v, vitamin metabolism; r, riboflavin metabolism; cb, carbohydrate metabolism; nu, nucleic acid metabolism; pu, purine metabolism; a, amino acid metabolism; gi, genetic information processing; $t$, translation; I, lipid metabolism; tca, citrate cycle; e, energy metabolism; c, carbon fixation, in this case reductive glyoxylate cycle.

The response to a combination of $\mathrm{Zn}$ and $\mathrm{PO}_{4}{ }^{3-}$ scarcity was considerably different, particularly for proteins in high abundance under $\mathrm{PO}_{4}{ }^{3-}$ scarcity (Figure 5A; Table 2). None of the proteins were the same as the Tetu et al. (2009) transcriptome study. Most notable was the influence on two key $\mathrm{PO}_{4}{ }^{3-}$ acquisition proteins: the alkaline phosphatase and phosphate transporter described above (Figures 7B,C), which were only modestly affected by $\mathrm{PO}_{4}{ }^{3-}$ limitation under $\mathrm{Zn}$ scarcity. In 


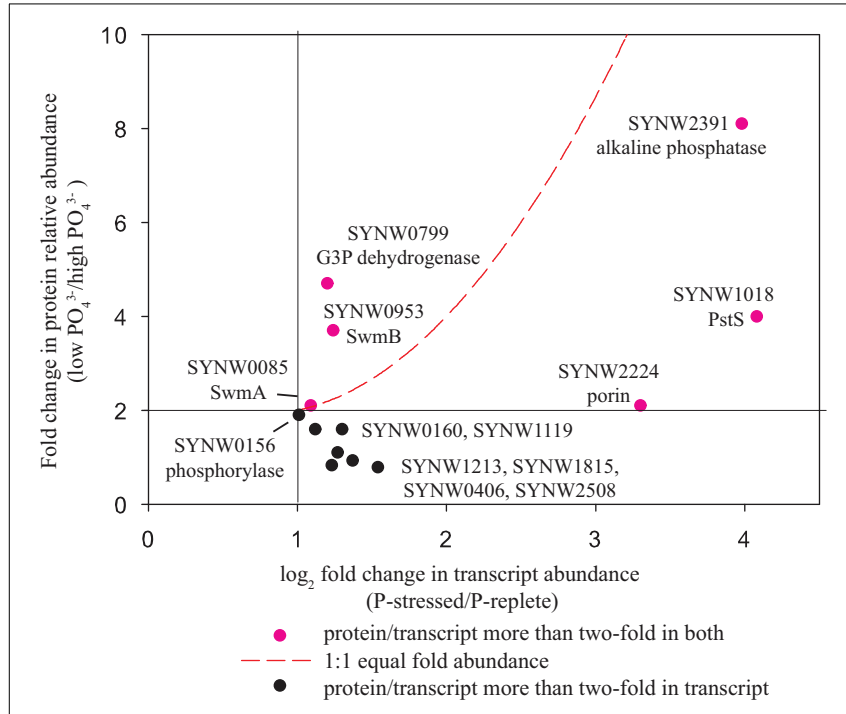

FIGURE 6 | Fold change in protein relative abundance (this experiment) as ratio of low phosphate to high phosphate vs. $\log _{2}$ fold change in gene relative abundance (Tetu et al., 2009) as ratio of P-stressed to P-replete. Pink dots represent proteins/transcripts more than two-fold abundant in both protein and transcript data. Black dots represent proteins/transcripts more than two-fold abundant in transcript data. Red dashed line indicates a 1:1 equal fold abundance. SYNW0160 conserved hypothetical protein; SYNW1119 6-phosphogluconate dehydrogenase; SYNW1213 thioredoxin peroxidase; SYNW1815 ABC transporter, substrate binding protein, phosphate; SYNW0406 hypothetical protein; SYNW2508 molecular chaperone DnaK2, heat shock protein hsp 70-2. See Tables 1, 2

addition, bacterial metallothionein did not increase in abundance with scarce $\mathrm{PO}_{4}{ }^{3-}$ (Figure 7A). Together these responses suggest a regulatory response to $\mathrm{Zn}$ that prevents synthesis of the metalloenzyme alkaline phosphatase when a necessary metal cofactor is absent. We should caveat that the metal atom center has not been demonstrated to be $\mathrm{Zn}$ for this alkaline phosphatase isoform, and other metals may also have functionality (or even be the "intended" metal), and that marine cyanobacteria including Synechococcus sp. WH8102, S. bacillaris, and Prochlorococcus MED4 have all been shown to have little to no $\mathrm{Zn}$ requirement (Sunda and Huntsman, 1995; Saito et al., 2002, 2003), although this has not been tested under conditions of organic $\mathrm{PO}_{4}{ }^{3-}$ utilization. In addition, our results suggest that the hypothetical protein SYNW1661 may be involved in the phosphate stress response in the presence of zinc (Table 1). Together, these observations suggest that $\mathrm{Zn}$ nutritional levels are connected to the $\mathrm{PO}_{4}{ }^{3-}$ response in this cyanobacterium.

Many proteins decreased in abundance in response to $\mathrm{PO}_{4}{ }^{3-}$ scarcity under low $\mathrm{Zn}$ conditions, such as a number of ribosomal proteins found in lower abundance that are likely related to the depressed growth rates (Table 2). A number of hypothetical proteins were also observed to increase in response to $\mathrm{PO}_{4}{ }^{3-}$ stress under Zn scarcity, including SYNW0380, 1145, 0670, 0827, and 0340 (Table 2). These proteins could be responsible for $\mathrm{PO}_{4}{ }^{3-}$ acquisition and utilization at scarce $\mathrm{Zn}$ and $\mathrm{PO}_{4}{ }^{3-}$, levels consistent with conditions encountered by cyanobacteria in the ocean. SYNW0380 could be directly involved in metal binding.

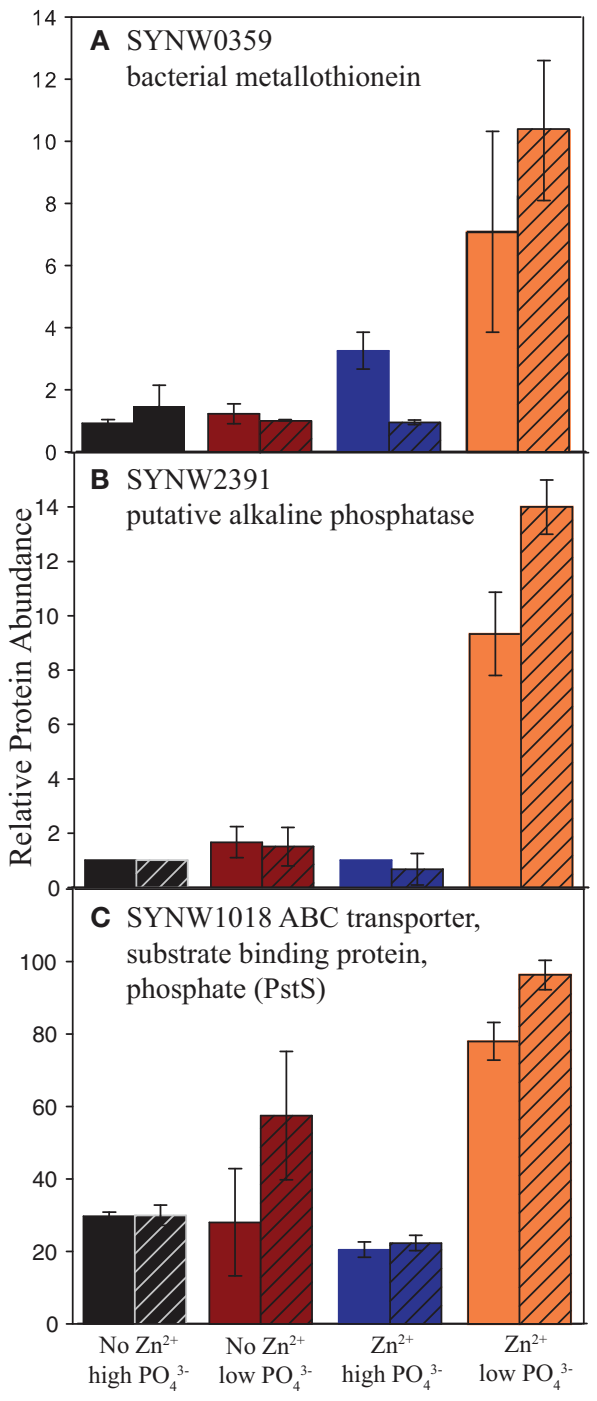

Treatment

FIGURE 7 | Relative protein abundances of SYNW0359 bacterial metallothionein, SYNW2391 putative alkaline phosphatase, and SYNW1018 ABC transporter, substrate binding protein, phosphate (PstS). Hatched bars were subjected to short-term Cd additions. Error bars are the standard deviation of duplicate injections. Note greater relative abundances of the alkaline phosphatase and PstS in the $1 \mu \mathrm{M} \mathrm{PO}_{4}{ }^{3-}$

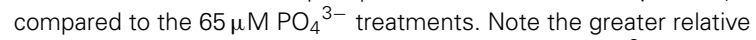
abundances of the alkaline phosphatase in the $1 \mu \mathrm{M} \mathrm{PO}_{4}{ }^{3-}$ treatments with Zn compared to no Zn.

It contains 239 total amino acid residues, 10 of these are cysteine and 14 histidine. There are two domains with the sequence -CXXC-.

\section{RESPONSE OF ALKALINE PHOSPHATASE ISOFORMS TO LOW PHOSPHATE}

Four genes in the genome of WH8102 are annotated as alkaline phosphatases, SYNW0120 putative alkaline phosphatase-like protein, SYNW0196 putative alkaline phosphatase, SYNW2390 putative alkaline phosphatase/5' nucleotidase, and SNW2391 putative alkaline phosphatase (phoA). In addition, SYNW1799 is 

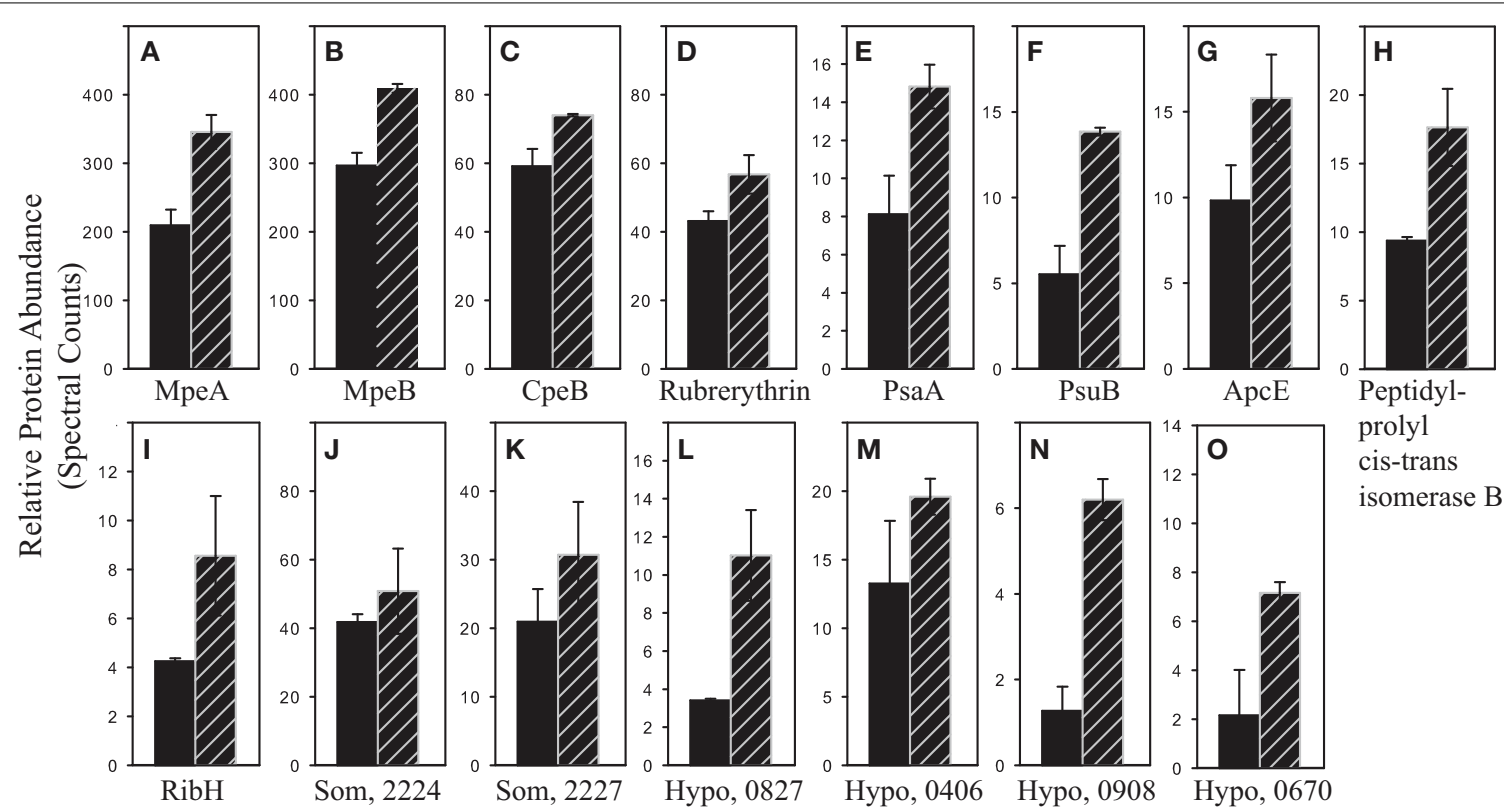

cis-trans

isomerase $\mathrm{B}$

FIGURE 8 | Proteins more abundant with short-term cadmium addition. Relative protein abundances of proteins two-fold or more greater in abundance and/or statistically different by Fisher's Exact Test in the no $\mathrm{Zn} / 65 \mu \mathrm{M} \mathrm{PO}_{4}{ }^{3-} /+$ $4.4 \mathrm{pM} \mathrm{Cd}^{2+}$ (hatched bars) compared to the no $\mathrm{Zn} / 65 \mu \mathrm{M} \mathrm{PO}_{4}{ }^{3-}$ treatments (solid bars). (A) SYNW2009 C-phycoerythrin class II, a chain, (B) SYNW2008 C-phycoerythrin class II, $\beta$ chain, (C) SYNW2017 C-phycoerythrin class I, $\beta$ chain, (D) SYNW2369 rubrerythrin, (E) SYNW2124 PSI P700 (PsaA), (F) SYNW3191
PSII extrinsic precursor (PsuB), (G) SYNW0486 anchor polypeptide $\mathrm{L}_{C M}$ (ApcE) (H) SYNW1264 peptidyl-prolyl cis-trans isomerase, (I) SYNW0082 riboflavin synthase subunit b (RibH), (J) SYNW2224 possible porin (Som, 2224), (K) SYNW2227 possible porin (Som, 2227), (L) SYNW0827 hypothetical protein (Hypo, 0827), (M) SYNW0406 hypothetical protein (Hypo, 0406), (N) SYNW0908 hypothetical protein (Hypo, 0908), and (0) SYNW0670 hypothetical protein (Hypo, 0670). Error bars are the standard deviation of duplicate injections.
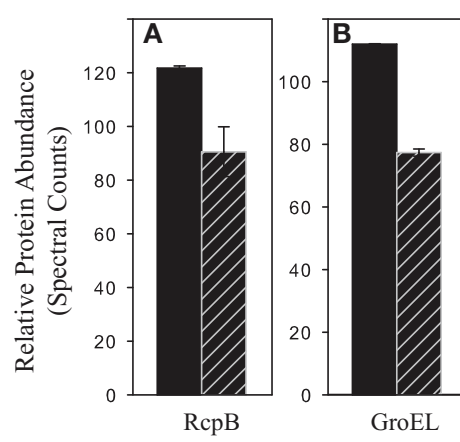

FIGURE 9 |Proteins more abundant without short-term cadmium addition. Relative protein abundances of proteins more than two-fold less abundant and/or statistically different by Fisher's Exact Test in the no $\mathrm{Zn} / 65 \mu \mathrm{M} \mathrm{PO}{ }^{3-} /+4.4 \mathrm{pM} \mathrm{Cd}^{2+}$ (hatched bars) compared to the no $\mathrm{Zn} / 65 \mu \mathrm{M} \mathrm{PO}{ }_{4}{ }^{3-}$ treatments (solid bars). (A) SYNW2022

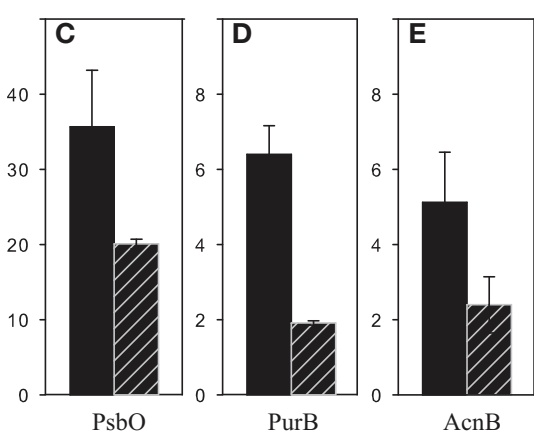

R-phycocyanin II, $\beta$ chain (RpcB), (B) SYNW0514 chaperonin GroEL (GroEL), (C) SYNW0303 PSII Mn-stabilizing polypeptide (PsbO), (D) SYNW0405 fumarate lyase: adenylosuccinate lyase (PurB), and (E) SYNW2500 aconitate hydratase (AcnB). Error bars are the standard deviation of duplicate injections. an alkaline phosphatase (phoX) (Kathuria and Martiny, 2011). Alkaline phosphatases vary in cellular location and associated metal ions. Two alkaline phosphatases purified from different strains of Vibrio cholerae, a $\gamma$-proteobacteria, acted on a variety of organic $\mathrm{PO}_{4}{ }^{3-}$ esters, but showed different levels of reactivation upon addition of $\mathrm{Na}^{+}, \mathrm{K}^{+}$, and $\mathrm{Mg}^{2+}$ ions (Roy et al., 1982). Some alkaline phosphatases (PhoA) are thought to be located in the periplasm and are activated by $\mathrm{Zn}$ and $\mathrm{Mg}$, whereas other alkaline phosphatases (PhoX, PhoD) are activated by calcium ions $\left(\mathrm{Ca}^{2+}\right)$ (Luo et al., 2009). A recent survey of the metagenomic databases concluded that $p h o X$ appeared to be more widespread in the ocean than phoA (Sebastian and Ammerman, 2009). There are also other types of alkaline phosphatases in cyanobacteria. The freshwater cyanobacterium Synechococcus 7942 contains a phoV in addition to phoA (Wagner et al., 1995). PhoV had broad substrate specificity for phosphomonoesters, required $\mathrm{Zn}^{2+}$ for activity and was inhibited by $\mathrm{PO}_{4}{ }^{3-}$, but was inhibited by $\mathrm{Mn}^{2+}$ (Wagner et al., 1995). Recent experimentation on PhoX (SYNW1799) overexpressed in E. coli have shown enhanced enzyme activity in the presence of $\mathrm{Ca}$, leading the authors to 
conclude that bacterial lineages with the presence of $p h o X$ in the genome may not be subject to $\mathrm{Zn}-\mathrm{P}$ colimitation (Kathuria and Martiny, 2011).

We detected SYNW2391 and SYNW1799, but not SYNW0120, SYNW2390 or SYN0196 as proteins in this experiment. SYNW2391 alkaline phosphatase (PhoA) is depicted in Figure 7, but SYNW1799 alkaline phosphatase (PhoX) was only detected by a few counts without significant abundance changes in our experimental matrix using our current detection capabilities, implying it is a relatively low abundance protein. This observation is contrary to what one might expect from a PhoX that does not presumably require $\mathrm{Zn}$. Due to the high ratio of $\mathrm{Ca} / \mathrm{Zn}$ in the ocean and in our medium, one would expect either low $\mathrm{Zn}$ or $\mathrm{PO}_{4}{ }^{3-}$ to result in the abundance of a Ca-alkaline phosphatase, particularly if the Ca-alkaline phosphatase has a lower specific activity than $\mathrm{Zn}$-alkaline phosphatases. These protein results suggest that PhoX may not be as important as recently stated in the literature by metagenomic analysis by Sebastian and Ammerman (2009), assuming extrapolation from this physiological culture experiment to natural populations of cyanobacteria in the ocean, although further study would be required on this point.

\section{METALLOTHIONEIN IN Synechococcus WH8102}

Metallothioneins are small, cysteine-rich, approximately 56 amino acid residue proteins involved in chelating metals such as $\mathrm{Zn}, \mathrm{Cd}$, copper $(\mathrm{Cu})$, silver, mercury, and arsenic (Duncan et al., 2006). Their exact function is elusive but metallothioneins may function as (i) metal resistance proteins for detoxifying $\mathrm{Zn}, \mathrm{Cd}$, and $\mathrm{Cu}$; (ii) reservoirs for the storage of excess $\mathrm{Zn}$ and/or $\mathrm{Cu}$ than can be mobilized under metal limiting conditions; (iii) metal chaperones that deliver $\mathrm{Zn}$ to $\mathrm{Zn}$-dependent proteins; and/or (iv) antioxidants that scavenge oxygen radicals (Palmiter, 1998). They are known to bind, sequester, and buffer intracellular $\mathrm{Zn}$ in freshwater cyanobacteria (Robinson et al., 2001). Metallothionein relative protein abundances in this study were elevated with $\mathrm{Zn}$ added and interestingly this effect was accentuated by low $\mathrm{PO}_{4}{ }^{3-}$, suggesting a possible link to $\mathrm{PO}_{4}{ }^{3-}$ acquisition since alkaline phosphatase requires $\mathrm{Zn}$ (Figure 7). It seems likely that metallothionein could be acting as a metal reservoir supplying alkaline phosphatase with $\mathrm{Zn}$. More quantitative analyses using a triple quadrupole mass spectrometer would be useful to constrain metallothionein change in WH8102. Ultimately, metallothionein may have developed as a relatively simple protein solution for cyanobacteria to cope with changing metal concentrations and increasing oxidation of the oceans over time, and may be important in the handling of $\mathrm{Zn}, \mathrm{Cd}$, and $\mathrm{Cu}$ in these organisms in the modern ocean.

\section{INFLUENCES OF SHORT-TERM CD EXPOSURE}

We also explored the influences of Cd addition on Synechococcus with a varying matrix of $\mathrm{Zn}$ and $\mathrm{PO}_{4}{ }^{3-}$ conditions. Previous studies noted the chemical correlation of $\mathrm{Cd}$ with $\mathrm{PO}_{4}{ }^{3-}$ in the ocean (Boyle et al., 1976; Boyle, 1988; Elderfield and Rickaby, 2000; Hendry et al., 2008), Cd replacement of $\mathrm{Zn}$ in the enzyme carbonic anhydrase (Lee et al., 1995; Lane et al., 2005; Xu et al., 2008), and have hypothesized that $\mathrm{Cd}$ replaces $\mathrm{Zn}$ in alkaline phosphatase (Morel et al., 2003). In this study, we observed a more pronounced $\mathrm{Cd}$ response during $\mathrm{Zn}$ and $\mathrm{PO}_{4}{ }^{3-}$ scarcity compared to replete conditions of each, suggesting that the sensitivity of natural populations to representative concentrations of Cd inputs may be greater than shown from culture studies performed with higher than ambient concentrations. We briefly discuss six proteomic responses in the following paragraphs: (1) Cd sensitivities at low nutrient concentrations, (2) Zn sensitivities at low $\mathrm{PO}_{4}{ }^{3-}$, (3) a buffering effect of $\mathrm{Zn}$ for $\mathrm{Cd}$ and effects on (4) photosynthetic (5) carbohydrate metabolism and (6) unknown function proteins. We finish by discussing the curious physiological response.

The WH8102 proteome was Cd-sensitive at lower nutrient concentrations. At low $\mathrm{PO}_{4}{ }^{3-}$, Cd had a greater effect on the proteome, based on the greater overall number of differentially abundant proteins (Figure 5B). Under scarce $\mathrm{Zn}$ conditions, Cd additions resulted in 32 proteins differentially abundant at low $\mathrm{PO}_{4}{ }^{3-}$ (Figure 5B, Supplementary Table 1E), compared to only 10 proteins differentially abundant in total at high $\mathrm{PO}_{4}{ }^{3-}$ (Figure 5B; Table 3). Cd addition at low $\mathrm{PO}_{4}{ }^{3-}$ resulted in three hypothetical proteins of unknown function becoming less abundant, suggesting a unique response to scarce nutrients (Table 3 ). These proteins could be important to nutrient acquisition in natural populations, warranting further scrutiny. In addition, this organism may be more vulnerable to $\mathrm{Cd}$ with scarce $\mathrm{Zn}$ because only four proteins were more abundant in the no $\mathrm{Zn} /$ low $\mathrm{PO}_{4}{ }^{3-}$ /shortterm Cd (Figure 5A, Supplementary Table 1B), including SwmB and PstS. Because these two proteins were not differentially abundant at no $\mathrm{Zn} /$ low $\mathrm{PO}_{4}{ }^{3-}$, perhaps short-term $\mathrm{Cd}$ addition stimulated the presence of these proteins (Table 2).

Short-term Cd exposure also showed an influence when varying $\mathrm{Zn}$ abundances particularly in the low $\mathrm{PO}_{4}{ }^{3-}$ treatments (Supplementary Table 1). With Cd exposure under low Zn, a component of the ABC phosphate transporter (SYNW1815, provisional PstS) and four other proteins were more abundant (Figure 5C, Supplementary Table 1J), whereas added Zn resulted in four more abundant proteins including bacterial metallothionein, putative alkaline phosphatase, and probable glutathione reductase (NADH) (Figures 5C, 7, Supplementary Table 1J). Glutathione may be involved in intracellular Cd binding. As mentioned above, greater metallothionein and alkaline phosphatase abundances with added $\mathrm{Zn}$ are consistent with $\mathrm{Zn}$ involvement in these proteins, either by being bound or in the active site.

The Cd sensitivity described above was largely ameliorated with added Zn (Figure 5A; Table 1, Supplementary Table 1A). For example, 5 of the 9 proteins more abundant at $\mathrm{Zn} / \mathrm{low}$ $\mathrm{PO}_{4}{ }^{3-}$ /short-term Cd relative to $\mathrm{Zn} /$ high $\mathrm{PO}_{4}{ }^{3-}$ /short-term Cd were also differentially abundant at $\mathrm{Zn} /$ low $\mathrm{PO}_{4}{ }^{3-}$ without $\mathrm{Cd}$ addition (Figure 5A; Table 1, Supplementary Table 1A). Four of these five proteins were also expressed as transcripts in the microarray experiment and are $\mathrm{PO}_{4}{ }^{3-}$ stress-related (Figure 5A; Table 1, Supplementary Table 1A). Bacterial metallothionein is the fifth protein, only found in the replete $\mathrm{Zn}$ without $\mathrm{Cd}$ addition (Figure 7). The presence of these proteins in $\mathrm{Zn}$ treatments suggests that the main proteins known to be involved in the $\mathrm{PO}_{4}{ }^{3-}$ response were more responsive to the presence of $\mathrm{Zn}$ than $\mathrm{Cd}$. 
Heavy metal interference in photosynthesis has been previously observed in plant systems (Sujak, 2005). As well as phycobilisome proteins observed during $\mathrm{PO}_{4}{ }^{3-}$ scarcity, six of the eight proteins more abundant in the scarce $\mathrm{Zn}$ short-term $\mathrm{Cd}^{2+}$ high $\mathrm{PO}_{4}{ }^{3-}$ treatment are involved in photosynthesis (two phycobilisome, three Photosystem II and one Photosystem I proteins) (Figure 5A), suggesting Cd interference in photosynthesis (Figure 5A, Supplementary Table 1A). These protein responses are consistent with the higher short-term growth rates after $\mathrm{Cd}$ addition, and $\mathrm{Cd}$ may have stimulated short-term carbon fixation at low $\mathrm{PO}_{4}{ }^{3-}$ (Figure 3, see next section). As with high $\mathrm{PO}_{4}{ }^{3-}$, differentially abundant proteins with $\mathrm{Cd}$ addition decreased with added $\mathrm{Zn}$ at low $\mathrm{PO}_{4}{ }^{3-}$ (Figure 5B, Supplementary Table 1G). Cd may have stimulated carbon fixation because $\delta$-aminolevulinic acid dehydratase, an enzyme in the chlorophyll biosynthesis pathway, and putative carboxysome structural peptide (CsoS2), involved in carbon fixation, were more abundant. Yet, Cd addition may have also had negative metabolic impacts: the no added Cd treatment had five proteins differentially more abundant compared to with $\mathrm{Cd}$ addition, including a hypothetical protein and a protein involved in each of lipid, purine, carbohydrate, and amino acid metabolism (Supplementary Table 1G).

Short-term Cd exposure appeared to affect carbohydrate metabolism. Changes in genes and proteins associated with carbohydrate flux under oxidative and Cd stress has been observed in eukaryotic organisms (Godon et al., 1998; Ralser et al., 2007; Guo et al., 2012). In this study, Cd addition with scarce $\mathrm{Zn}$ and high $\mathrm{PO}_{4}{ }^{3-}$ caused five proteins to be significantly less abundant, including two involved in carbohydrate metabolism, two involved in photosynthesis and one in protein folding (Figures 5B, 7; Table 3, Supplementary Table 1C). Again, Cd in the absence of $\mathrm{Zn}$ may negatively affect the photosynthetic apparatus and additionally, carbohydrate production.

Three proteins of unknown function (SYNW0908, 0670 and 0827) became more abundant with $\mathrm{Cd}$ addition under scarce $\mathrm{Zn}$ and replete $\mathrm{PO}_{4}{ }^{3-}$ conditions (Figures 5B, 8; Table 3). An additional protein of unknown function (SYNW0406) was determined statistically different by Fisher's Exact Test (Figure 8; Supplementary Table 1C). These hypothetical proteins might be involved in Cd handling with scarce $\mathrm{Zn}$ or part of the general $\mathrm{Cd}$ response, because they were not differentially abundant with added Zn. Two of these proteins (SYNW0670 and 0827) are also more abundant with scarce $\mathrm{Zn}$ and $\mathrm{PO}_{4}{ }^{3-}$ stress. Five of the 10 additional proteins significantly different by Fisher's Exact Test in these two treatments are involved in photosynthesis further supporting Cd interference in the photosynthetic process (Figure 8; Supplementary Table 1C).

\section{A CURIOUS SHORT-TERM PHYSIOLOGICAL RESPONSE TO CD ADDITION AT LOW $\mathrm{PO}_{4}{ }^{3-}$ AND ADDED ZN}

Instantaneous $(24 \mathrm{~h})$ growth rates and higher cell abundances in the $\mathrm{Zn} /$ low $\mathrm{PO}_{4}{ }^{3-}$ /short-term $\mathrm{Cd}$ addition imply that $\mathrm{Cd}$ may have been used as a nutrient (Figures 3F,G). This could result from direct $\mathrm{Cd}$ usage as a nutrient or more likely by release of a nutritive intracellular $\mathrm{Zn}$ pool due to $\mathrm{Cd}$ exposure; as discussed above metallothionein is one possible "Zn buffer" (Frausto da Silva and Williams, 1991) and in mammals upon Cd and $\mathrm{Cu}$ loading, metallothionein releases Zn (Zhang et al., 2003). The "nutritive" Cd effect was not observed in any other treatments, although all combinations of $\mathrm{Zn}$ and $\mathrm{PO}_{4}{ }^{3-}$ showed slight growth rates increases with short-term $\mathrm{Cd}$ addition and the $\mathrm{Zn} /$ low $\mathrm{PO}_{4}{ }^{3-}$ combination showed a slight increase in final cell abundances with short-term $\mathrm{Cd}$ addition. Only the $\mathrm{Zn} / \mathrm{low}$ $\mathrm{PO}_{4}{ }^{3-}$ treatment showed a large difference in both. Instantaneous growth rates in the $\mathrm{Zn}$ treatments at both $\mathrm{PO}_{4}{ }^{3-}$ levels during the last $24 \mathrm{~h}$ increased by factors of $\sim 2$ and 1.7 with short-term $\mathrm{Cd}$ addition relative to no added Cd (Figure 3F). In contrast, hardly an increase in instantaneous growth rates was observed in the no $\mathrm{Zn}$ treatments, both low and high $\mathrm{PO}_{4}{ }^{3-}$ with the $\mathrm{Cd}$ addition relative to no $\mathrm{Cd}$ added (Figure $3 \mathbf{F}$ ).

The low dosage Cd stimulation we observed may be a hormetic effect and the mechanism, albeit unknown, could be in the interaction with $\mathrm{Zn}$. A hormetic response is defined as low dosage stimulation with higher dosage toxicity (Calabrese, 2005). Cd responses at varying concentrations would be required to observe a full hormetic curve, as has been documented in mammalian cellular systems (Misra et al., 2002, 2003; Mantha and Jumarie, 2010). Although the descriptor hormetic was not used, low Cd concentrations stimulated the growth of Chlorella, a photosynthetic eukaryotic organism, and inhibited growth at higher concentrations (Vallee and Ulmer, 1972). Alternative to Zn displacement by $\mathrm{Cd}$, Cd could directly have a nutritive or regulatory effect inducing cell division, although the latter effect has only been observed in eukaryotic systems to date (Misra et al., 2002, 2003; Sobkowiak and Deckert, 2003). Non-redundant pBLAST searches of mitotic cyclin b1-type and p38 mitogen activated protein kinase [from eukaryotic systems studied by Misra et al. (2002) and Sobkowiak and Deckert (2003)] yielded no hits against Synechococcus sp. WH8102 (Altschul et al., 1997), suggesting this microbe's Cd response is not modulated by these systems as observed elsewhere. Using this data set, we cannot distinguish between nutritive effects of Cd caused by intracellular $\mathrm{Zn}$ release upon $\mathrm{Cd}$ exposure or because of $\mathrm{Cd}$ alone.

\section{CONCLUSIONS}

In conclusion, the physiologic response of Synechococcus WH8102 to short-term $\mathrm{Cd}^{2+}$ addition under four varying $\mathrm{Zn}$ and $\mathrm{PO}_{4}{ }^{3-}$ treatments $\left[\mathrm{Zn} /\right.$ high $\mathrm{PO}_{4}{ }^{3-}$, no $\mathrm{Zn} /$ low $\mathrm{PO}_{4}{ }^{3-}$, no $\mathrm{Zn} /$ high $\mathrm{PO}_{4}{ }^{3-}$, and no $\mathrm{Zn} /$ low $\mathrm{PO}_{4}{ }^{3-}$ ] revealed during the last $24 \mathrm{~h}$ of the experiment relative to the high $\mathrm{PO}_{4}{ }^{3-}$ conditions: $\mathrm{i}$ ) increased growth rates under low $\mathrm{PO}_{4}{ }^{3-}$ conditions and ii) even greater increased growth rates with $\mathrm{Cd}$ addition under low $\mathrm{PO}_{4}{ }^{3-}$ and $\mathrm{Zn}$ conditions. The proteomic response revealed differential abundances of $\mathrm{PO}_{4}{ }^{3-}$ stress proteins and differential protein abundances with chronic $\mathrm{Zn}$ and $\mathrm{Cd}$ addition. Considering the proteomic data, it appears that $\mathrm{Zn}$ nutrition is an important component of the known $\mathrm{PO}_{4}{ }^{3-}$ response in this organism because of the difference in response to $\mathrm{PO}_{4}{ }^{3-}$ with and without $\mathrm{Zn}$. These findings are consistent with the ideas that $\mathrm{Zn}$ is beneficial for the functioning of alkaline phosphatase and other proteins involved in $\mathrm{PO}_{4}{ }^{3-}$ acquisition, and at environmentally relevant $\mathrm{PO}_{4}{ }^{3-}$ concentrations the presence of $\mathrm{Zn}$ and $\mathrm{Cd}$ make a difference in the physiology and proteome of cells, perhaps 
by influencing regulation. Greater abundances of hypothetical proteins in some treatments relative to others suggest these proteins may be involved in phosphate, cadmium and zinc stress or combinations thereof. Bacterial metallothionein appears to be regulated with alkaline phosphatase, suggesting a Zn-handling mechanism in which alkaline phosphatase is supplied with $\mathrm{Zn}$ by metallothionein. In addition to proteins of unknown function, Cd affected photosynthetic and carbohydrate metabolism proteins, and appeared to have the greatest overall effect on the proteome at low $\mathrm{PO}_{4}{ }^{3-}$ and $\mathrm{Zn}$.

Comparison of proteomic data to literature transcriptome analyses shows a similar response of many important phosphate stress related proteins [putative alkaline phosphatase, periplasmic $\mathrm{ABC}$ phosphate binding protein (PstS), motility-related proteins (SwmA and SwmB), and possible porin)] but also shows other proteins that did not respond in the microarray study, such as bacterial metallothionein (SmtA), as well as proteins that did respond in the microarray study and not this one, like thioredoxin peroxidase. These data suggest that there is a fair amount of consistency between the transcriptome and proteome under phosphate stress. Taken together with the fact that the treatments without $\mathrm{Zn}$ showed a different proteomic reaction to phosphate stress, the presence of $\mathrm{Zn}$ appears important to the phosphorus metabolism of this open ocean cyanobacterium.

\section{ACKNOWLEDGMENTS}

We would like to thank Erin Bertrand, Tyler Goepfert, Dawn Moran, Abigail Noble and the late Vladimir Bulygin. We also thank John Waterbury and Freddy Valois for the Synechococcus sp. WH8102, use of lab space and discussion. We are grateful to thesis committee members Ed Boyle, Sonya Dyhrman, Carl Lamborg, and Nigel Robinson for discussion and comments on earlier versions of this manuscript. We thank the reviewers for their helpful comments that improved this manuscript. We would like to thank the Gordon and Betty Moore Foundation (\#2724), C-MORE, the Office of Naval Research, and NSF Chemical Oceanography (OCE-1031271, OCE-1233261, OCE-1220484) for support.

\section{SUPPLEMENTARY MATERIAL}

The Supplementary Material for this article can be found online at: http://www.frontiersin.org/journal/10.3389/fmicb. 2013.00387/abstract

\section{REFERENCES}

Altschul, S. F, Madden, T. L., Schäffer, A. A., Zhang, J., Zhang, Z., Miller, W., et al. (1997). Gapped BLAST and PSI-BLAST: a new generation of protein database search programs. Nucleic Acids Res. 25, 3389-3402. doi: 10.1093/nar/25.17.3389

Blindauer, C. A. (2008). Zinc-handling in cyanobacteria: an update. Chem. Biodivers. 5, 1990-2013. doi: 10.1002/cbdv.200890183

Boyle, E. A. (1988). Cadmium: chemical tracer of deepwater paleoceanography. Paleoceanography 3, 471-489. doi: 10.1029/PA003i004p00471

Boyle, E.A., Sclater, F., and Edmond, J. M. (1976). On the marine geochemistry of cadmium. Nature 263, 42-44. doi: 10.1038/263042a0

Bruland, K. W. (1980). Oceanographic distributions of cadmium, zinc, nickel, and copper in the North Pacific. Earth Planet. Sci. Lett. 47, 176-198. doi: 10.1016/0012-821X(80)90035-7

Bruland, K. W. (1992). Complexation of cadmium by natural organic ligands in the central North Pacific. Limnol. Oceanogr. 37, 1008-1017. doi: 10.4319/lo.1992.37.5.1008
Calabrese, E. J. (2005). Toxicological awakenings: the rebirth of hormesis as a central pillar of toxicology. Toxicol. Appl. Pharmacol. 204, 1-8. doi: 10.1016/j.taap.2004.11.015

Cox, A. D. (2011). Interactions of Cadmium, Zinc, and Phosphorus in Marine Synechococcus: Field Uptake, Physiological and Proteomic Studies. Ph.D. dissertation, MIT/WHOI Joint Program in Chemical Oceanography.

Cullen, J. (2006). On the nonlinear relationship between dissolved cadmium and phosphate in the modern global ocean: could chronic iron limitation of phytoplankton growth cause the kink? Limnol. Oceanogr. 51, 1369-1380. doi: 10.4319/lo.2006.51.3.1369

Duncan, K. E. R., Ngu, T. T., Chan, J., Salgado, M. T., Merrifield, M. E., and Stillman, M. J. (2006). Peptide folding, metal-binding mechanisms, and binding site structures in metallothioneins. Exp. Biol. Med. 231, 1488-1499.

Dyhrman, S. T., Jenkins, B. D., Rynearson, T. A., Saito, M. A., Mercier, M. L., Alexander, H., et al. (2012). The transcriptome and proteome of the diatom Thalassiosira pseudonana reveal a diverse phosphorus stress response. PLoS ONE 7:e33768. doi: 10.1371/journal.pone.0033768

Eisen, M. B., Spellman, P. T., Brown, P. O., and Bostein, D. (1998). Cluster analysis and display of genome-wide expression patterns. Proc. Natl. Acad. Sci. U.S.A. 95, 14863-14868. doi: 10.1073/pnas.95.25.14863

Elderfield, H., and Rickaby, R. E. M. (2000). Oceanic Cd/P ratio and nutrient utilization in the glacial Southern Ocean. Nature 405, 305-310. doi: $10.1038 / 35012507$

Frausto da Silva, J. R. R., and Williams, R. J. P. (1991). The Biological Chemistry of the Elements: The Inorganic Chemistry of Life. New York, NY: Oxford University Press.

Fuller, N. J., Marie, D., Partensky, F., Vaulot, D., Post, A. F., and Scanlan, D. J. (2003). Clade-specific 16S ribosomal DNA oligonucleotides reveal the predominance of a single marine Synechococcus clade in a stratified water column in the Red Sea. Appl. Environ. Microbiol. 69, 2430-2443. doi: 10.1128/AEM.69.5.24302443.2003

Godon, C., Lagniel, G., Lee, J., Buhler, J. M., Kieffer, S., Perrot, M., et al. (1998). The $\mathrm{H}_{2} \mathrm{O}_{2}$ stimulon in Saccharomyces cerevisiae. J. Biol. Chem. 273, 22480-22489. doi: 10.1074/jbc.273.35.22480

Goericke, R., and Welschmeyer, N. A. (1993). The marine prochlorophyte Prochlorococcus contributes significantly to phytoplankton biomass and primary production in the Sargasso Sea. Deep Sea Res. 40, 2283-2294. doi: 10.1016/0967-0637(93)90104-B

Goldschmidt, V. M. (1954). Geochemistry. Edited by Alex Muir. Oxford: Clarendon Press.

Guo, L., Ghassemian, M., Komives, E., and Russell, P. (2012). Cadmium-induced proteome remodeling regulated by Spc1/Sty1 and Zip1 in fission yeast. Toxicol. Sci. 129, 200-212. doi: 10.1093/toxsci/kfs179

Hendry, K. R., Rickaby, R. E. M., de Hoog, J. C. M., Weston, K., and Rehkämper, M. (2008). Cadmium and phosphate in coastal Antarctic seawater: implications for southern ocean nutrient cycling. Mar. Chem. 112, 149-157. doi: 10.1016/j.marchem.2008.09.004

Karl, D. M. (2000). Phosphorus, the staff of life. Nature 406, 31-32. doi: $10.1038 / 35017683$

Kathuria, S., and Martiny, A. C. (2011). Prevalence of a calcium-based alkaline phosphatase associated with the marine cyanobacterium Prochlorococcus and other ocean bacteria. Environ. Microbiol. 13, 74-83. doi: 10.1111/j.14622920.2010.02310.x

Lane, E. S., Semeniuk, D. M., Strzepek, R. F., Cullen, J. T., and Maldonado, M. T. (2009). Effects of iron limitation on intracellular cadmium of cultured phytoplankton: implications for surface dissolved cadmium to phosphate ratios. Mar. Chem. 115, 55-162. doi: 10.1016/j.marchem.2009. 07.008

Lane, T. W., and Morel, F. M. M. (2000). A biological function for cadmium in marine diatoms. Proc. Natl. Acad. Sci. U.S.A. 97, 4627-4631. doi: 10.1073/pnas.090091397

Lane, T. W., Saito, M. A., George, G. N., Pickering, I. J., and Prince, R. C. (2005). A cadmium enzyme from a marine diatom. Nature 435, 42. doi: 10.1038/435042a

Lee, J. G., and Morel, F. M. M. (1995). Replacement of zinc by cadmium in marine phytoplankton. Mar. Ecol. Prog. Ser. 127, 305-309. doi: 10.3354/meps 127305

Lee, J. G., Roberts, S. B., and Morel, F. M. M. (1995). Cadmium: a nutrient for the marine diatom Thalassioria weissflogii. Limnol. Oceanogr. 40, 1056-1063. doi: 10.4319/lo.1995.40.6.1056 
Li, W. K. W. (1995). Composition of ultraphytoplankton in the central North Atlantic. Mar. Ecol. Prog. Ser. 122, 1-8. doi: 10.3354/meps122001

Liu, H., Nolla, H. A., and Campbell, L. (1997). Prochlorococcus growth rate and contribution to primary production in the equatorial and subtropical North Pacific Ocean. Aquat. Microbial Ecol. 12, 39-47. doi: 10.3354/ame012039

Luo, H., Benner, R., Long, R. A., and Hu, J. (2009). Subcellular localization of marine bacterial alkaline phosphatases. Proc. Natl. Acad. Sci. 106, 21219-21223. doi: 10.1073/pnas.0907586106

Mantha, M., and Jumarie, C. (2010). Cadmium-induced hormetic effect in differentiated Caco-2 cells: ERK and p38 activation without cell proliferation stimulation. J. Cell. Physiol. 224, 250-61. doi: 10.1002/jcp.22128

Misra, U. K., Gawdi, G., Akabani, G., and Pizzo, S. V. (2002). Cadmium-induced DNA synthesis and cell proliferation in macrophages: the role of intracellular calcium and signal transduction mechanisms. Cell. Signal. 14, 327-340. doi: 10.1016/S0898-6568(01)00268-6

Misra, U. K., Gawdi, G., and Pizzo, S. V. (2003). Induction of mitogenic signalling in the $1 \mathrm{LN}$ prostate cell line on exposure to submicromolar concentrations of cadmium ${ }^{+}$. Cell. Signal. 15, 1059-1070. doi: 10.1016/S0898-6568(03) 00117-7

Morel, F. M. M., Milligan, A. J., and Saito, M. A. (2003). "Marine bioinorganic chemistry: the role of trace metals in the oceanic cycles of major nutrients," in Treatise on Geochemistry. The Oceans and Marine Geochemistry, Vol. 6, eds H. Elderfield, H. D. Holland, and K. K. Turekian (Oxford: Elsevier-Pergamon), 113-143. doi: 10.1016/B0-08-043751-6/06108-9

Morel, F. M. M., Reinfelder, J. R., Roberts, S. B., Chamberlain, C. P., Lee, J. G., and Yee, D. (1994). Zinc and carbon co-limitation of marine phytoplankton. Nature 369, 740-742. doi: 10.1038/369740a0

Palenik, B., Brahamsha, B., Larimer, F. W., Land, M., Hauser, L., Chain, P., et al. (2003). The genome of a motile marine Synechococcus. Nature 424, 1037-1042. doi: 10.1038/nature01943

Palmiter, R. D. (1998). The elusive function of metallothioneins. Proc. Natil. Acad. Sci. U.S.A. 95, 8428-8430. doi: 10.1073/pnas.95.15.8428

Park, H., Song, B., and Morel, F. M. M. (2007). Diversity of the cadmiumcontaining carbonic anhydrase in marine diatoms and natural waters. Environ. Microbiol. 9, 403-413. doi: 10.1111/j.1462-2920.2006.01151.x

Peng, J., Elias, J. E., Thoreen, C. C., Licklider, L. J. and Gygi, S. P. (2003). Evaluation of multidimensional chromatography coupled with tandem mass spectrometry (LC/LC-MS/MS) for large-scale protein analysis: the yeast proteome. J. Proteome Res. 2, 43-50. doi: 10.1021/pr025556v

Price, N. M., and Morel, F. M. M. (1990). Cadmium and cobalt substitution for zinc in a marine diatom. Nature 344, 658-660. doi: 10.1038/ $344658 \mathrm{a} 0$

Ralser, M., Wamelink, M. M., Kowald, A., Gerisch, B., Herren, G., Struys, E. A., et al. (2007). Dynamic rerouting of the carbohydrate flux is key to counteracting oxidative stress. J. Biol. 6, 10. doi: 10.1186/jbiol61

Robbins, L. J., Lalonde, S. V., Saito, M. A., Planavsky, N. J., Mloszewska, A. M., Pecoits, E., et al. (2013). Authigenic iron oxide proxies for marine zinc over geological time and implications for eukaryotic metallome evolution. Geobiology 11, 295-306. doi: 10.1111/gbi.12036

Robinson, N. J., Whitehall, S. K., and Cavet, J. S. (2001). Microbial metallothioneins. Adv. Microbial Physiol. 44,183-213. doi: 10.1016/S0065-2911(01) 44014-8

Rocap, G., Distel, D. L., Waterbury, J. B., and Chisholm, S. W. (2002). Resolution of Prochlorococcus and Synechococcus ecotypes by using 16S-23S ribosomal DNA internal transcribed spacer sequences. Appl. Environ. Microbiol. 68, 1180-1191. doi: 10.1128/AEM.68.3.1180-1191.2002

Roy, N. K., Ghosh, R. K., and Das, J. (1982). Monomeric alkaline phosphatase of Vibrio cholerae. J. Bacteriol. 150, 1033-1039.

Saito, M., Moffett, J. W., Chisholm, S. W., and Waterbury, J. B. (2002). Cobalt limitation and uptake in Prochlorococcus. Limnol. Oceanogr. 47, 1629-1636. doi: 10.4319/lo.2002.47.6.1629

Saito, M. A., Goepfert, T. J., Noble, A. E., Bertrand, E. M., Sedwick, P. N., and DiTullio, G. R. (2010). A seasonal study of dissolved cobalt in the Ross Sea, Antarctica: micronutrient behavior, absence of scavenging, and relationships with Zn, Cd, and P. Biogeosciences 7, 4059-4082. doi: 10.5194/bg-74059-2010

Saito, M. A, Goepfert, T. J., and Ritt, J. (2008). Some thoughts on the concept of colimitation: three definitions and the importance of bioavailability. Limnol. Oceanogr. 53, 276-290. doi: 10.4319/lo.2008.53.1.0276
Saito, M. A., Sigman, D. M., and Morel, F. M. M. (2003). The bioinorganic chemistry of the ancient ocean: the co-evolution of cyanobacterial metal requirements and biogeochemical cycles at the Archean-Proterozoic boundary? Inorg. Chim. Acta 356, 308-318. doi: 10.1016/S0020-1693(03)00442-0

Scanlan, D. J. (2003). Physiological diversity and niche adaptation in marine Synechococcus. Adv. Microbial Physiol. 47, 1-64. doi: 10.1016/S0065-2911(03) 47001-X

Sebastian, M., and Ammerman, J. W. (2009). The alkaline phosphatase PhoX is more widely distributed in marine bacteria than the classical PhoA. ISME J. 3 , 563-572. doi: 10.1038/ismej.2009.10

Shaked, Y., Xu, K., Leblanc, K., and Morel, F. M. M. (2006). Zinc availability and alkaline phosphatase activity in Emiliania huxleyi: implications for Zn-P co-limitation in the ocean. Limnol. Oceanogr. 51, 299-309. doi: 10.4319/lo.2006.51.1.0299

Smith, R. A., and Martell, A. E. (1993). NIST Critical stability constants for metal complexes database, Standard reference database 46. Gaithersburg, MD: U.S. Department of Commerce.

Sobkowiak, R., and Deckert, J. (2003). Cadmium-induced changes in growth and cell cycle gene expression in suspension-culture cells of soybean. Plant Physiol. Biochem. 41, 767-772. doi: 10.1016/S0981-9428(03)00101-3

Sujak, A. (2005). Interaction between cadmium, zinc and silver-substituted platocyanin and cytochrome b6f complex-heavy metals toxicity towards photosynthetic apparatus. Acta Physiologiae Plantarum 27, 61-69. doi: 10.1007/s11738005-0037-z

Sunda, W. G., and Huntsman, S. A. (1995). Cobalt and zinc interreplacement in marine phytoplankton: biological and geochemical implications. Limnol. Oceanogr. 40, 1404-1417. doi: 10.4319/lo.1995.40.8.1404

Sunda, W. G., and Hunstman, S. A. (1998). Control of Cd concentrations in a coastal diatom by interactions among free ionic $\mathrm{Cd}, \mathrm{Zn}$, and $\mathrm{Mn}$ in seawater. Environ. Sci. Technol. 32, 2961-2968. doi: 10.1021/es980271y

Sunda, W. G., and Huntsman, S. A. (2000). Effect of Zn, Mn, and Fe on Cd accumulation in phytoplankton: implications for oceanic Cd cycling. Limnol. Oceanogr. 45, 1501-1516. doi: 10.4319/lo.2000.45.7.1501

Tai, V., Paulsen, I. T., Phillippy, K., Johnson, D. A., and Palenik, B. (2009). Wholegenome microarray analyses of Synechococcus-Vibrio interactions. Environ. Microbiol. 11, 2698 -2709. doi: 10.1111/j.1462-2920.2009.01997.x

Tetu, S. G., Brahamsha, B., Johnson, D. A., Tai, V., Phillippy, K., Palenik, B., et al. (2009). Microarray analysis of phosphate regulation in the marine cyanobacterium Synechococcus sp. WH8102. ISME J. 3, 835-849. doi: 10.1038/ismej.2009.31

Vallee, B. L., and Ulmer, D. D. (1972). Biochemical effects of mercury, cadmium and lead. Аnnu. Rev. Biochem. 41, 91-128. doi: 10.1146/annurev.bi.41.070172.000515

Veldhuis, M. J. W., Kraay, G. W., Van Bleijswijk, J. D. L., and Baars, M. A. (1997). Seasonal and spatial variation in phytoplankton biomass, productivity and growth in the northwestern Indian Ocean: the southwest and northeast monsoon, 1992-1993. Deep Sea Res. 44, 425-449. doi: 10.1016/S09670637(96)00116-1

Wagner, K. U., Masepohl, B., and Pistorius, E. K. (1995). The cyanobacterium Synechococcus sp. strain PCC 7942 contains a second alkaline phosphatase encoded by phoV. Microbiology 141, 3049-3058. doi: 10.1099/13500872-14112-3049

Waldron, K. J., and Robinson, N. J. (2009). How do bacterial cells ensure that metalloproteins get the correct metal? Nat. Rev. Microbiol. 7, 25-35. doi: 10.1038/nrmicro2057

Waterbury, J. B., Watson, S. W., Valois, F. W., and Franks, D. G. (1986). Biological and ecological characterization of the marine unicellular cyanobacterium Synechococcus. Can. Bull. Fish. Aquat. Sci. 214, 71-120.

Wurch, L. L., Bertrand, E. M., Saito, M. A., van Mooy, B. A. S, and Dyhrman, S. T. (2011). Proteome changes driven by phosphorus deficiency and recovery in the brown tide-forming alga, Aureococcus anophagefferens. PLoS ONE 6:e28949. doi: 10.1371/journal.pone.0028949

Xu, Y., Feng, L., Jeffrey, P. D., Shi, Y., and Morel, F. M. M. (2008). Structure and metal exchange in the cadmium carbonic anhydrase of marine diatoms. Nature 452, 56-61. doi: 10.1038/nature06636

Zhang, B., Georgiev, O., Hagmann, M., Günes, Ç., Cramer, M., Faller, P., et al. (2003). Activity of metal-responsive transcription factor 1 by toxic heavy metals and $\mathrm{H}_{2} \mathrm{O}_{2}$ in vitro is modulated by metallothionein. Mol. Cell. Biol. 23, 8471-8485. doi: 10.1128/MCB.23.23.8471-8485.2003 
Zhang, B., VerBerkmoes, N. C., Langston, M. A., Uberbacher, E., Hettich, R. L., and Samatova, N. F. (2006). Detecting differential and correlated protein expression in label-free shotgun proteomics. J. Proteome Res. 5, 2909-2918. doi: $10.1021 /$ pr0600273

Zwirglmaier, K., Heywood, J. L., Chamberlain, K., Woodward, E. M., Zubkov, M. V., and Scanlan, D. J. (2007). Basin-scale distribution patterns of picocyanobacterial lineages in the Atlantic Ocean. Environ. Microbiol. 9, 1278-1290. doi: 10.1111/j.1462-2920.2007. 01246.x

Conflict of Interest Statement: The authors declare that the research was conducted in the absence of any commercial or financial relationships that could be construed as a potential conflict of interest.
Received: 07 October 2013; accepted: 26 November 2013; published online: 17 December 2013.

Citation: Cox AD and Saito MA (2013) Proteomic responses of oceanic Synechococcus WH8102 to phosphate and zinc scarcity and cadmium additions. Front. Microbiol. 4:387. doi: 10.3389/fmicb.2013.00387

This article was submitted to Microbiological Chemistry, a section of the journal Frontiers in Microbiology.

Copyright (c) 2013 Cox and Saito. This is an open-access article distributed under the terms of the Creative Commons Attribution License (CC BY). The use, distribution or reproduction in other forums is permitted, provided the original author(s) or licensor are credited and that the original publication in this journal is cited, in accordance with accepted academic practice. No use, distribution or reproduction is permitted which does not comply with these terms. 